\title{
Post-industrial Trajectories of Mediterranean European Cities: The Case of Post-Olympics Athens
}

\author{
Aspa Gospodini \\ [Paper first received, September 2007; in final form, January 2009]
}

\begin{abstract}
This paper deals with clusters of post-industrial urban economies and their impacts on the spatial restructuring and the relandscaping of the contemporary inner city. It investigates such impacts by studying recent economic, spatial and landscape transformations of Athens, a large Mediterranean city in the geographical and economic periphery of Europe. The first part of the paper reviews earlier research on clusters of post-industrial urban economies and their spatial impacts, while attempting to present the topic in an international context. The second part focuses on a case study of Athens, Greece. It examines the planned clusters of athletics, culture and leisure that were developed for the 2004 Olympics; and, the spontaneous clusters of both culture, leisure and creative activities, and technology-intensive and knowledge-rich activities and advanced financial intermediary services that have gradually developed in Athens' inner-city areas during the past decade. The paper documents land use shifts and landscape transformations while highlighting the processes of formation of these spontaneous clusters and the urban policies involved; it also discusses urban governance issues in relation to the management of Athens' clusters, both planned and spontaneous. Finally, it draws conclusions about differences in post-industrial trajectories among large cities in the core of Europe and large Mediterranean cities in the developing periphery of Europe.
\end{abstract}

\section{Introduction: The Rise of Post-industrial Urban Economies and Their Spatial Impacts on Cities}

Since the early 1990s, European and American cities in advanced economies, as well as some metropolitan cities in Asian growth regions, have been experiencing the flourishing of certain economic sectors, termed 'new urban economies' by McNeil and While (2001). Thes authors have identified a fourfold typology; agglomeration economies, informational and

Aspa Gospodini is in the Department of Planning and Regional Development, University of Thessaly, Pedion Areos, 38334 Volos, Greece. E-mail: gospod@uth.gr. 
knowledge-rich economies, technopoles and the urban leisure economy. Among these, cultural and leisure economies and informational technologies are the most widespread and perhaps the most visible manifestations of economic novelty in cities. In the new milieu of economic globalisation, volatility of capital and enterprises, and intercity competition (Jensen-Butler, 1997), the relocation of traditional industries in developing regions has been accompanied by an unprecedented growth of cultural, leisure and informational industries in mature cities. Cultural and leisure production and consumption (of arts, fashion, music, food, tourism), creative industries of technology-intensive and knowledge-rich enterprises containing design (in architecture, fashion, graphics, Internet, etc.), new media and ICTs have become the growth engines of the post-industrial city (see Zukin, 1991 and 1995; Bianchini, 1993; Lash and Urry, 1995; Castells, 1996; Scott, 1997 and 2000, Clarke, 1997; Hall, 2000).

In urban history, transitions from one socioeconomic paradigm to another have almost always entailed shifts in the city's spatial organisation, structure and landscape-as typically evinced, for instance, in the transformations of European cities following the evolution from feudalism to the Renaissance. In our era, the development of post-industrial urban economies has undoubtedly been affecting cities as spatial entities (see Bailly et al., 1996; Hutton, 2000; Lever, 2001; Shaw, 2001). As Hutton (2000) convincingly argued, impacts seem to be much stronger than those witnessed in the mid 20th century under Fordist economies. More specifically, since the 1990s, the rise of new specialised services-mainly concerning informatics and information technology, innovation and design, cultural production, global financial intermediaries and international megaprojects consortia-has marked major shifts in the urban economy, society and space. These third-generation services, considered as a new "integrated service-technology production system" (Hutton, 2000, p. 290; Hutton, 2004b; Scott, 1997) are the growth engine fuelling the urban economy. They have robust social effects, giving rise to a new species of workerhigh-tech staff and knowledge workers - and generating a new middle class (Harvey, 1989; Featherstone, 1989; Soja, 1989 and 2000; Short, 1989; Martin, 1998; Florida, 2002, 2004 and 2005) with a new consumption ethic and a higher sensitivity to urban heritage, protection of the natural environment and aesthetics. Also, they have strong spatial effects by: rearranging urban networks and upgrading certain cities in global hierarchies as 'service poles' (Hutton, 2000, p. 290) for example, Seattle, Hong Kong, Barcelona and Milan; clustering in inner-city areas, thereby sifting/ expanding the city's spatial core and altering its spatial organisation and structure; and, becoming a key catalyst for urban renewal and redevelopment, thereby reshaping the urban landscape and re-imaging the city (Hannigan, 1998 and 2003; Evans, 2003; Hutton, 2004a, 2004b and 2006; Gospodini, 2006). Regarding the evolution of urban landscapes since the mid 20th century, if someone labelled the modern city of the 1950s, 1960s and 1970s as the city of land use zoning and homogeneous and non-hierarchical multinucleis landscape, then the post-industrial city would be the city of eclectic clustering of flourishing economies, with heterogeneous and hierarchical multinucleis landscape (Leontidou, 1993; Gospodini, 2006).

In this framework, the phenomenon of clustered post-industrial economic activities in inner city areas has lately become a central concern of urbanists. As evidence, we can cite the growing number of studies that describe, analyse and document in various case study cities, the formation and development of clusters-for example: clusters of new media and ICTs (see Attfield, 1997; Pratt, 2000; Graham and Guy, 2002); clusters of television and film-making (see Krätke, 2002; 
Basset et al., 2002; Turok, 2003; De Propris and Hypponen, 2008); music clusters (Belussi and Sedita, 2008); clusters of leisure and the night-time economy (see Hobbs et al., 2000; Hitters and Richards, 2002; Hollands and Chatterton, 2003; Hubbard, 2003; Roberts, 2006); clusters of fashion design (see Crewe, 1996; Creigh-Tyte, 2005); clusters of ethnic restaurants and ethnic fashion (see Shaw et al., 2004); or various clusters in the metropolis as a whole, reflecting individual post-industrial trajectories (see for instance, Hutton, 2004a). This corpus of research so far suggests that post-industrial trajectories may vary from site to site and from city to city, but there is still common ground which may enable an understanding of the broader phenomenon. The main questions addressed are: what are the advantages of clustering? Which urban policies encourage the formation and development of clusters? Are there different patterns of clustering and/or types of cluster?

\section{Clustered Post-industrial Economies, Shifted Urban Policies and Glocalised Urban Landscapes}

Some studies focus on the advantages of clustering - the pull factors and the networking synergies produced, for example, in clusters of technology-intensive and knowledgerich activities (see Capello, 1999; Keeble and Wilkinson, 1999; Lawson and Lorenz, 1999; Pratt, 2000; Raffo et al., 2000; Krätke, 2002) and clusters of cultural and leisure activities (see Scott, 1997 and 2006; Hitters and Richards, 2002; Mommas, 2004). This corpus of research erves to refute earlier conjectures (see for instance, Caincross, 1998; Coyle, 1998) projecting the radical possibilities of new technologies (such as e-commerce and e-advertising, e-mail, web-casting, cost-free and unlimited repro-duction and distribution of e-goods such as data and software on the clients' computers and video links) that would diminish the importance of face-to-face contacts among professionals, especially in the case of technology-intensive economic activities. However, research appears in many cases to indicate the contrary; there seems to be still a need for physical interaction among professionals in relation to the practices of learning, innovating, contracting and locating employment opportunities, as well as socialising, eating, relaxing or just feeling the 'pulse of the city' (see Pratt, 2000, in the case of new media). The pull factors and synergies encouraging clustering include a kind of localised collective learning, ${ }^{1}$ formal and informal links between firms, an increase in the degree of specialisation of skills and their diffusion, creating an abundant supply of appropriately qualified professionals, the growth of subsidiary trades and specialised services, the increased use of highly specialised equipment, interfirm mobility of staff and spin-offs of new firms and institutions from existing ones. As Keeble and Wilkinson (1999) argue, clusters of post-industrial economies are characterised by what Storper (1995) had termed 'untraded interdependencies' which extend beyond traditional customer-supplier and servicing relationships.

\section{Shaping and Managing Clusters and the Appropriate Policies}

A number of studies focus on policies concerning the formation, development and management of clusters. Newman and Smith (2000) argue that, despite recent urban politics literature emphasising local initiative and coalition building among partners in explaining successful cases of urban regeneration, the study of the London's South Bank cultural cluster highlighted the local council's failure in pulling partners together under a broad economic development agenda; it was the dynamic property market and central government interventions that steered the formation and development of this cluster. In contrast, in the case of the Witte de Withstraat cultural cluster in Rotterdam and the Westrgasfabriek 
cultural cluster in Amsterdam, Hitters and Richards (2002) argue that the local authorities' management strategies for clustering culture and leisure economic activities and the processes of renewal/redevelopment in an area may have had a critical role in shaping the variety of activities attracted, the cluster's degree of innovation and creativity as an incubation space and the area's new image and place identity after regeneration. To enhance a cluster's creativity and diversity, the institutional setting must be tolerant of competition and rivalry-between people and between ideas. This argument is supported by the studies of Lazzeretti (2008) and Costa (2008) who argue that a cluster's creativity is often enhanced in institutional settings that support spontaneity from the bottom-up. Along the the same lines, de Propris and Hypponen (2008) provide evidence that, in the case of the Hollywood film cluster, concentrated governance and global market pressures have thwarted creativity, leading to a blockbuster mentality that aims at replicating past successes rather than producing novelty.

\section{'Cluster-led Regeneration', New Types of Urban Space and Glocalised Landscapes}

A number of studies (see Hutton, 2004b; Gospodini, 2006) are concerned with the phenomenon of the 'cluster-led regeneration' of inner-city areas focusing on spatial and morphological features and on producing typologies that reflect the city's relandscaping. Hutton (2004b) recognises four emergent territorial forms of industrial production within the inner city, among which, 'signifying precincts' are the most evident and mature manifestations of inner-city transformations. Areas regenerated as 'signifying precincts' of the new economy (such as Hoxton in London and Yaletown in Vancouver) encompass major concentrations of the 'leading-edge' firms in key new economic sectors and offer special opportunities for social interaction and information exchange. They redefine attributes of consumption, lifestyle and urban imaginary, provide distinctive environmental amenities and contribute to the reformation of local identity.

Such 'signifying precincts' or new epicentres are analysed and classified (see Gospodini, 2006) according to spatial parameters, such as location, principal economic activities, supplementary land uses, production of space (development, redevelopment, renewal) and architectural and urban morphology. Four main types of epicentre are identified

(1) Entrepreneurial epicentres: clusters of advanced financial intermediary services and technology-intensive and knowledge-rich firms (such as Potzdamer Platz, Berlin; 'Citylife', Milan; One North, Singapore).

(2) High-culture epicentres: clusters of museums, galleries, theatres, operas, concert halls and the like (such as the museums quarter in Vienna, Rotterdam and The Hague) (see Mommas, 2004; Gospodini, 2006).

(3) Popular leisure epicentres: clusters of cafés, bars, restaurants and popularmusic clubs (such as Temple Bar, Dublin; Bagladcity, Brick Lane, London; Westergasfabriek, Amsterdam; Witte de Withstraat, Rotterdam).

(4) Culture and leisure waterfront epicentres: clusters of culture and leisure activities such as museums, convention halls, galleries, concert halls, theatres, theme parks and promenades (such as the South Bank, London; the Forum of the Cultures, Barcelona; Abandoibarra, Bilbão; Port Melbourne, Melbourne; West Kowloon, Hong Kong).

\section{Cluster-led Regeneration and the Question of Sustainability}

Regarding cluster-led-regeneration and the new types of urban space in the post-industrial 
city, a number of scholars raise questions about social inclusion/exclusion, displacement and sustainability (see Atkinson, 2000 and 2004; Aitchison and Evans, 2003; Miles and Paddison, 2005; Evans, 2005). Research on mega urban development and redevelopment projects—such as those usually involved in the creation of entrepreneurial epicentres and high-culture epicentres-has shown in a sample of 12 large European cities that most such projects have exacerbated physical and social fragmentation in the city (Swyngedouw et al., 2002). In culture-led regeneration in particular, Miles and Paddison (2005) observe that the degree to which new cultural policies may contribute to the reproduction of social inequality is often neglected by local authorities and urbanists, many of whom endorse a dominant rhetoric linking creative industries and post-industrial job generation, encouraging people to live in city centres and improve the urban quality of life-a rhetoric apparently fusing the economic, social and cultural aspects of regeneration. Within such a framework, social inclusion becomes determined by an individual's or a social group's relation to the marketplace and, by implication, to their role as consumers. However, sustainability in culture-led neighbourhood regeneration has to be considered not only in economic terms, but also for its social and political implications-for the capacity of cultural policy to be socially inclusive and to contribute to collective decisionmaking and social cohesion (Miles and Paddison, 2005; and Miles, 2005). In this regard, Aitchison and Evans (2003) have presented a list of 11 principles forming the basis of sustainable cultural projects that can contribute positively towards regeneration, renewal and inclusion.

The sustainability of epicentres of postindustrial economies seems to be related to their degree of multifunctionality-i.e. to the variety of economic sectors within a given cluster. Research in Greece so far ${ }^{2}$ shows that mono-functional clusters and epicentreseven those considered successful-bear a significant risk of recession after an initial boom (for instance, the rise and fall of dotcoms in the 1990s; see Ramachandran, 2003; Razi et al., 2004). In this respect, they tend to be less sustainable than multifunctional clusters and epicentres (Gospodini, 2006).

\section{Investigating the Trajectories of Different Classes and Groups Of Cities}

Given that the impacts of clustered-led regeneration in the inner city may vary from site to site and from city to city, urbanists need to develop a more systematic and theoretically fruitful appreciation of the differentiated outcomes (benefits and disbenefits) and to share knowledge about local impacts (economic, environmental and social) (Hutton this Special Issue). Within this conceptual framework, this paper attempts to contribute to an understanding of these issues by investigating the post-industrial trajectories of Athens, Greece-a large city in the developing south-eastern periphery of Europe. During the past decade, Athens has made great efforts to improve the quality and imagery of urban space and has been subject to major transformations associated with hosting the 2004 Olympic Games. Athens now lives in the echo of the Olympics and expects to capitalise on its efforts. Principal research questions include

(1) Do distinct classes and groups of cities (such as global cities, large cities with mature economies, large cities in the geographical and/or economic periphery of Europe like Mediterranean cities) exhibit different trajectories in terms of the formation and development of clusters?

(2) Do distinct types of epicentres of postindustrial economies, as emerging in European and American metropolitan cities, transform peripheral large cities in developing economies, like Athens? 
(3) To what extent are local authorities' policies and management strategies for clusters in post-industrial economies differentiated between metropolitan cities in mature economies and peripheral large cities in developing economies, like Athens?

\section{The Rise of Post-industrial Urban Economies in Athens, Attica and Greece}

Within the urban system of Greece, Athens is the capital and by far the most important city, exhibiting a concentration of all economic sectors and activities-especially high-level public administration, business headquarters and a wide array of servicesand accommodating a population of about 4 million in the greater metropolitan area of Attica. However, within the European urban system, Athens ranks low. According to different classifications of European cities, ${ }^{3}$ Athens is a peripheral large city with a low level of influence on the region (see Petrakos and Economou, 1999).

Since the 1990s, Greek cities, and especially Athens and the metropolitan area of Attica, have been experiencing the rise of postindustrial urban economic sectors and industries. Table 1 presents the growth of these economic sectors in respectively, Athens and the metropolitan area of Attica, and in Greece as a whole. The aggregate of these sectors in Athens and Attica represents 20.13 per cent of the total economic activities in terms of the number of enterprises and 16.25 per cent in terms of annual turnover. For Greece as a whole, their sum reaches 23.23 per cent of total economic activities in terms of number of enterprises, but it is only 14.73 per cent in terms of annual turnover. This means that there are many more such economic activities in the country as a whole, but that the most significant ones in terms of turnover are located in Athens and Attica. In examining individual sectors, as presented in Table 1, Athens and Attica exhibit higher values than Greece as a whole in almost all categories in terms of both number of enterprises and annual turnover. The only exception to this is the sector of night-time entertainment in which Greece as a whole appear to present higher values than Athens and Attica, reflecting the great number of night-time entertainment activities located on very popular tourist islands in the Aegean Sea, such as Rhodes, Crete, Santorini and Mykonos.

Figures 1 to 4 show the percentage of each economic sector within aggregate postindustrial economic activity in Athens and in Attica (Figures 1 and 2) and Greece as a whole (Figures 3 and 4). In terms of the number of enterprises (Figures 1 and 3), culture and leisure, and night-time entertainment appear to be the two most developed sectors, as they rank highest with percentages of 55 per cent and 40 per cent for culture and leisure, and 29 per cent and 50 per cent for night-time entertainment, in Athens and in Greece. The intermediary financial services sector ranks lowest with 2 per cent in each case. However, in examining the proportion of each sector

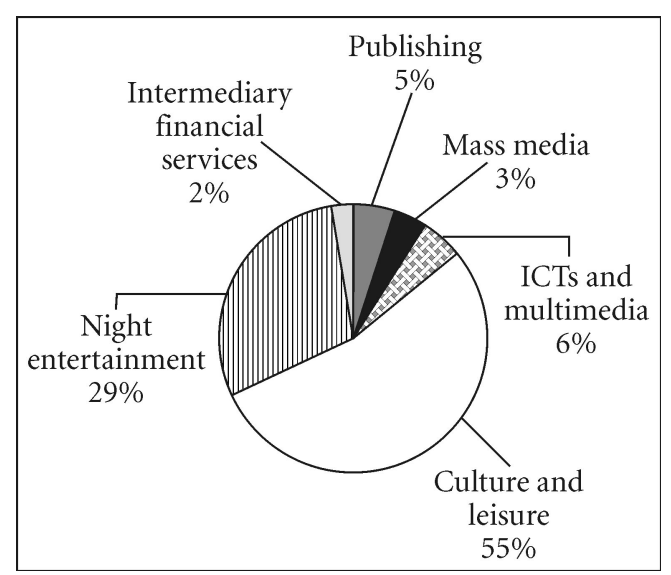

Figure 1. Athens and Attica: Thecontribution of each sector to total postindustrial economic activity in terms of total number of enterprises, 2000

Source: NSSG (2000). 


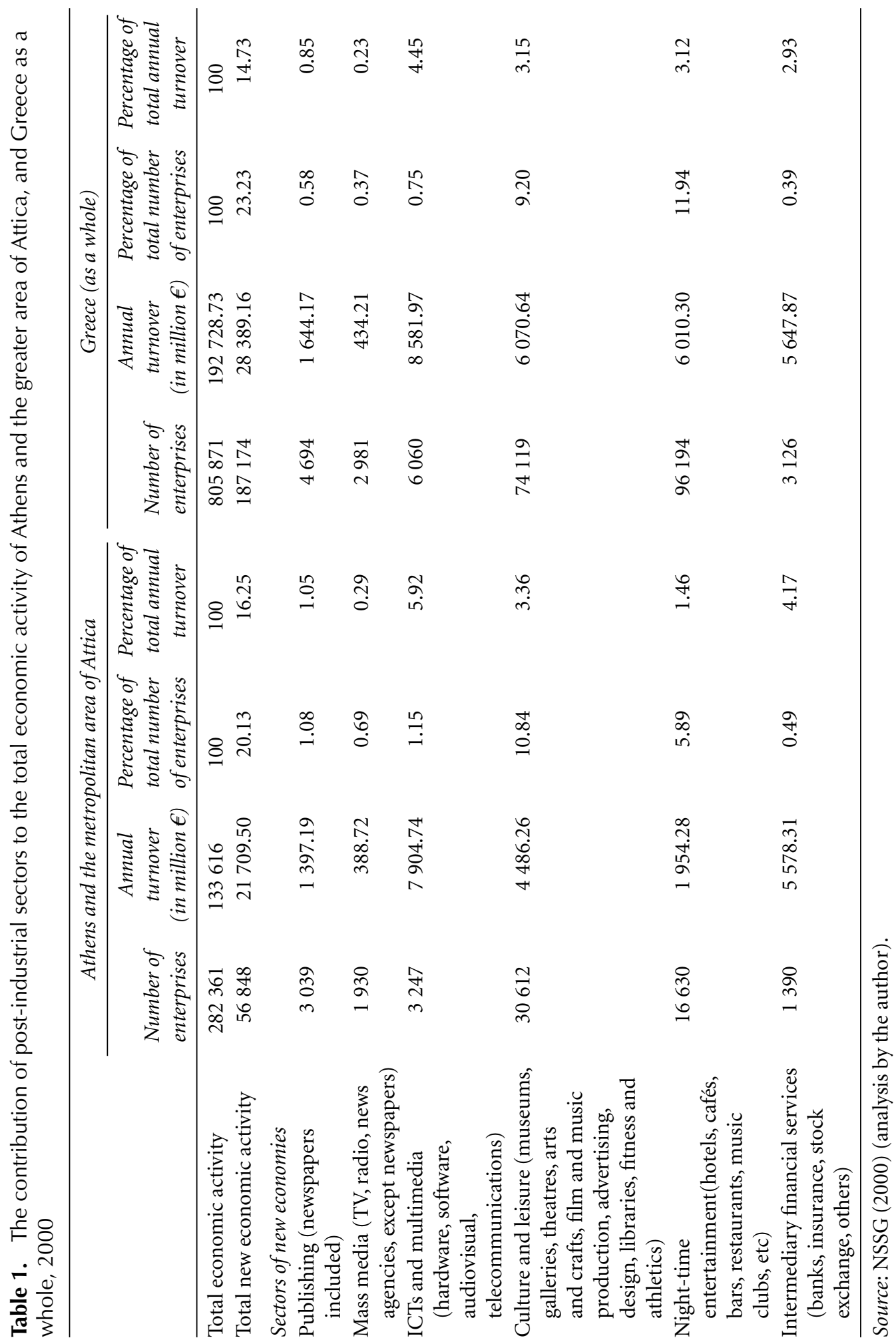




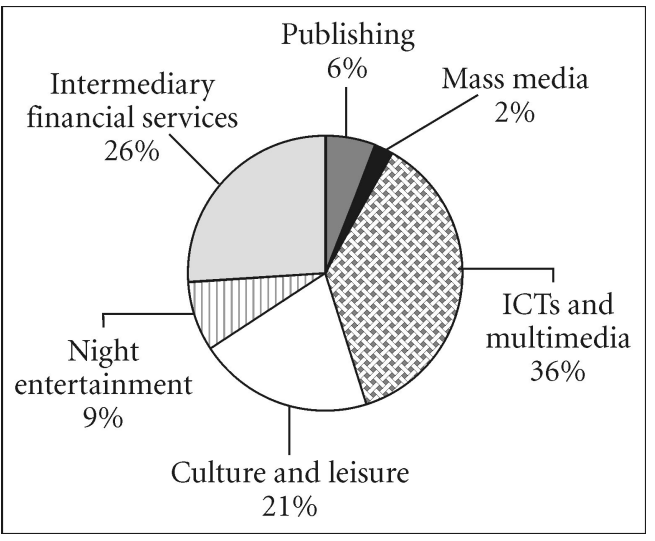

Figure 2. Athens and Attica: the contribution of each sector to total postindustrial economic activity in terms of total annual turnover, 2000

Source: NSSG (2000).

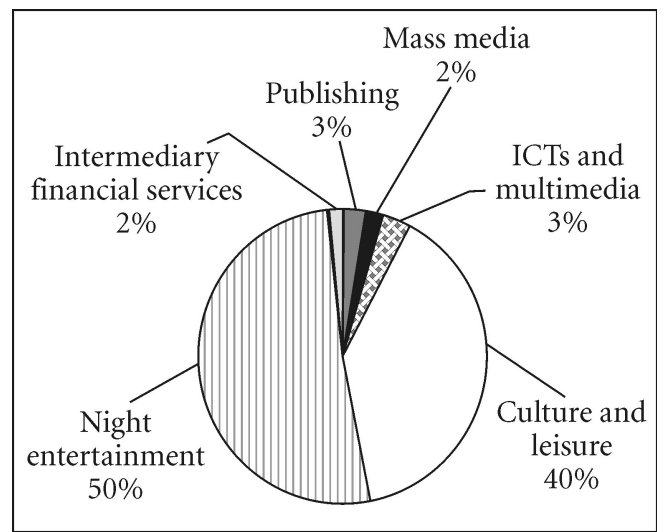

Figure 3. Greece: the contribution of each sector to total post-industrial economic activity in terms of total number of enterprises, 2000

Source: NSSG (2000).

in terms of annual turnover, this hierarchy alters radically; and the ICT and multimedia sectors rank highest with 36 per cent in Athens and Attica, and 30 per cent in Greece as a whole. The next places in the hierarchy are taken by intermediary financial services (26 per cent) in the case of Athens and Attica and by culture and leisure (21 per cent),

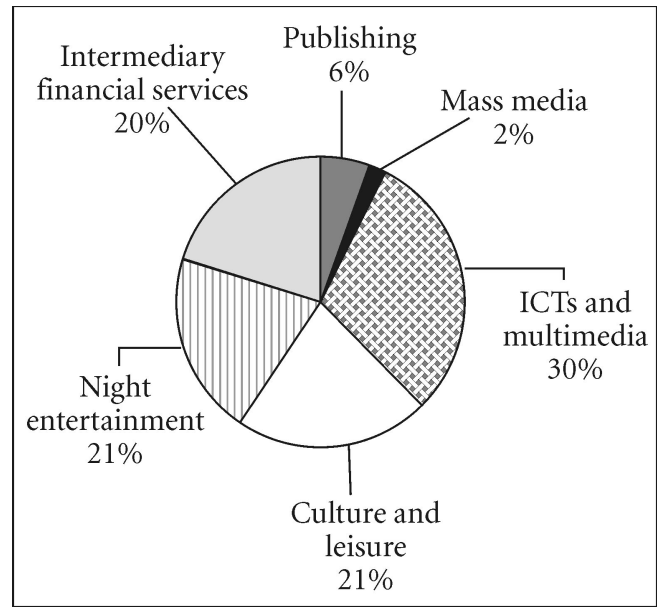

Figure 4. Greece: the contribution of each sector to total post-industrial economic activity in terms of Total Annual Turnover (2000)

Source: NSSG (2000).

night-time entertainment (21 per cent) and intermediary financial services (20 per cent), with almost equal percentages, in the case of Greece as a whole.

To understand the differences in the results of the analysis in terms of number of enterprises and annual turnover, one should note that: intermediary financial services, and especially banks, have been integrated and concentrated in a limited number of large international and national firms in the past two decades; there is a fast-growing number of enterprises in the culture and leisure sectors and night-time entertainment; but, many of them, especially enterprises in night-time entertainment, manage to declare only part of their annual turnover in order to escape taxation.

\section{A Typology of Post-industrial Clusters in Athens}

In the past 10 or 15 years, the growth of postindustrial sectors in Athens and Attica has reconfigured the city's spatial structure and has shaped a new landscape. Post-industrial 
economic formations can be grouped within two broad categories: clusters planned and constructed mainly by public funds; and clusters spontaneously developed mainly by private investments. The former-as presented in Table 2 - are typically sites hosting mainly athletic activities and have been produced by means of development and/or redevelopment during the city's preparation for the 2004 Olympic Games.

Most of the athletic complexes have been complemented by other amenities, such as convention and exhibition halls, commerce and entertainment, parks and promenades, with a view to improving the quality of urban space and the city's image. In this respect, they constitute clusters of culture and leisure. In terms of location, they are dispersed throughout the metropolitan district of Athens and Attica-inner-city areas, peripheral urban areas and the suburban fringe (Figure 5). In contrast to the successful international experience of many cities ${ }^{4}$ in taking advantage of mega events to regenerate large-inner city areas, Athens did not adopt such a strategy. Although there were indeed sites in former industrial inner areas (such as the area of Eleonas), projects for the 2004 Olympics were not clustered therein but, rather, were distributed throughout the metropolitan district of Attica-implying a strategy designed to promote a multinucleated urban regeneration

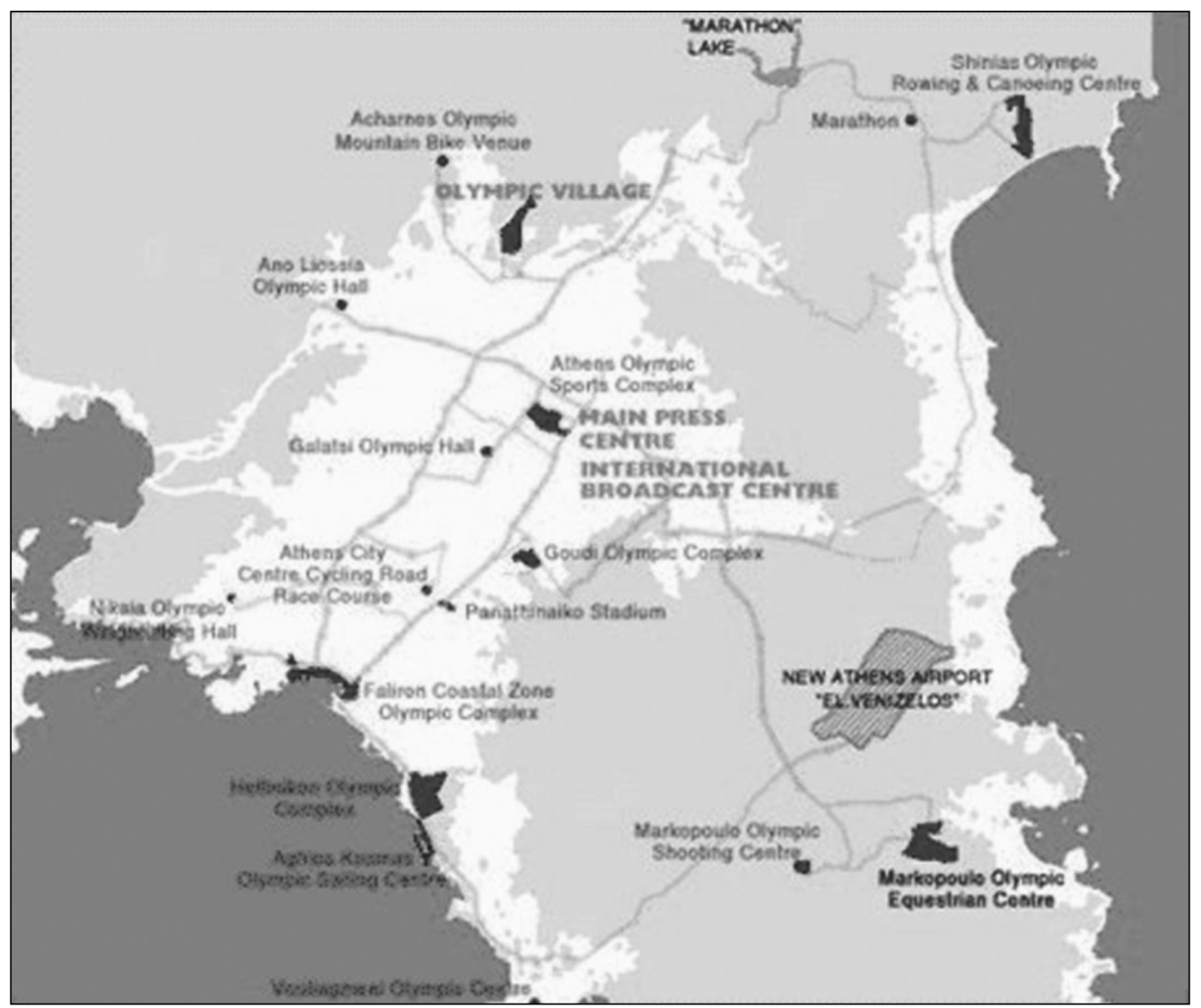

Figure 5. The metropolitan area of Attica, with the city of Athens and the major Olympic venues scattered throughout the area 
Table 2. Athens and Attica: clusters of athletics and leisure facilities planned and developed by public authorities for hosting the 2004 Olympic Games

\begin{tabular}{|c|c|c|c|c|}
\hline Name of cluster & Location & $\begin{array}{l}\text { Type of } \\
\text { development }\end{array}$ & $\begin{array}{l}\text { Main land uses and } \\
\text { activities clustered }\end{array}$ & $\begin{array}{l}\text { Complementary land } \\
\text { uses and activities }\end{array}$ \\
\hline $\begin{array}{l}\text { Athens Olympic } \\
\text { Sports Complex }\end{array}$ & $\begin{array}{l}\text { Marrousi } \\
\text { (north urban } \\
\text { periphery) }\end{array}$ & $\begin{array}{l}\text { Redevelopment } \\
+ \text { new } \\
\text { development }\end{array}$ & $\begin{array}{l}\text { Athletic activities } \\
\text { (athletics, basketball, } \\
\text { swimming and water } \\
\text { sports, tennis, indoor } \\
\text { cycling) }\end{array}$ & $\begin{array}{l}\text { Parks and } \\
\text { promenades, } \\
\text { convention halls, } \\
\text { exhibition halls, } \\
\text { commercial shops, } \\
\text { cafés, restaurants }\end{array}$ \\
\hline $\begin{array}{l}\text { Faliron Olympic } \\
\text { Coastal Zone } \\
\text { Complex }\end{array}$ & $\begin{array}{l}\text { Faliron Bay } \\
\text { waterfront } \\
\text { (inner city) }\end{array}$ & $\begin{array}{l}\text { Redevelopment } \\
+ \text { new } \\
\text { development }\end{array}$ & $\begin{array}{l}\text { Athletic activities } \\
\text { (volleyball, beach- } \\
\text { volleyball, handball, } \\
\text { tae-kwon-do) }\end{array}$ & $\begin{array}{l}\text { Parks and } \\
\text { promenades, } \\
\text { convention halls, } \\
\text { exhibition halls, } \\
\text { commercial shops, } \\
\text { cafes, restaurants }\end{array}$ \\
\hline $\begin{array}{l}\text { Goudi Olympic } \\
\text { Modern } \\
\text { Pentathlon } \\
\text { Complex }\end{array}$ & $\begin{array}{l}\text { Goudi } \\
\text { (inner city) }\end{array}$ & $\begin{array}{l}\text { Redevelopment } \\
+ \text { new } \\
\text { development }\end{array}$ & $\begin{array}{l}\text { Athletic activities } \\
\text { (modern pentathlon } \\
\text { and badminton) }\end{array}$ & $\begin{array}{l}\text { Parks and } \\
\text { promenades, } \\
\text { convention halls, } \\
\text { exhibition halls, } \\
\text { commercial shops, } \\
\text { cafes, restaurants }\end{array}$ \\
\hline $\begin{array}{l}\text { Galatsi Olympic } \\
\text { Complex }\end{array}$ & $\begin{array}{l}\text { Galatsi } \\
\text { (inner city) }\end{array}$ & $\begin{array}{l}\text { New } \\
\text { development }\end{array}$ & $\begin{array}{l}\text { Athletic activities } \\
\text { (table-tennis, } \\
\text { rhythmic gymnastics) }\end{array}$ & $\begin{array}{l}\text { Parks and convention } \\
\text { halls }\end{array}$ \\
\hline $\begin{array}{l}\text { Olympic Boxing } \\
\text { Hall of Peristeri }\end{array}$ & $\begin{array}{l}\text { Peristeri } \\
\text { (inner city) }\end{array}$ & $\begin{array}{l}\text { New } \\
\text { development }\end{array}$ & $\begin{array}{l}\text { Athletic activities } \\
\text { (boxing) }\end{array}$ & $\begin{array}{l}\text { Parks and convention } \\
\text { halls }\end{array}$ \\
\hline $\begin{array}{r}\text { Hellinikon } \\
\text { Olympic } \\
\text { Complex }\end{array}$ & $\begin{array}{l}\text { Glyfada } \\
\text { (south- } \\
\text { east urban } \\
\text { periphery }\end{array}$ & $\begin{array}{l}\text { new } \\
\text { development }\end{array}$ & $\begin{array}{l}\text { Athletic activities } \\
\text { (baseball, softball, } \\
\text { hockey, canoe/kayak, } \\
\text { handball, fencing). }\end{array}$ & $\begin{array}{l}\text { Parks and } \\
\text { promenades, } \\
\text { convention and } \\
\text { exhibition halls }\end{array}$ \\
\hline $\begin{array}{l}\text { Nikea Olympic } \\
\text { Indoor Hall }\end{array}$ & $\begin{array}{l}\text { Nikea } \\
\text { (west urban } \\
\text { periphery) }\end{array}$ & $\begin{array}{l}\text { New } \\
\text { development }\end{array}$ & $\begin{array}{l}\text { Athletic activities } \\
\text { (weight lifting) }\end{array}$ & $\begin{array}{l}\text { Parks and convention } \\
\text { halls }\end{array}$ \\
\hline $\begin{array}{l}\text { Ano Liosia } \\
\text { Olympic Indoor } \\
\text { Hall }\end{array}$ & $\begin{array}{l}\text { Liosia } \\
\text { (north-west } \\
\text { urban } \\
\text { periphery) }\end{array}$ & $\begin{array}{l}\text { New } \\
\text { development }\end{array}$ & $\begin{array}{l}\text { Athletic activities } \\
\text { (wrestling, judo) }\end{array}$ & $\begin{array}{l}\text { Parks and convention } \\
\text { halls }\end{array}$ \\
\hline $\begin{array}{l}\text { Markopoulo } \\
\text { Olympic } \\
\text { Equestrian } \\
\text { Centre }\end{array}$ & $\begin{array}{l}\text { Markopoulo } \\
\text { (east suburban } \\
\text { fringe) }\end{array}$ & $\begin{array}{l}\text { New } \\
\text { development }\end{array}$ & $\begin{array}{l}\text { Athletic activities } \\
\text { (equestrian events) }\end{array}$ & $\begin{array}{l}\text { Parks and } \\
\text { promenades, } \\
\text { convention and } \\
\text { exhibition halls }\end{array}$ \\
\hline $\begin{array}{l}\text { Markopoulo } \\
\text { Olympic } \\
\text { Shooting Centre }\end{array}$ & $\begin{array}{l}\text { Markopoulo } \\
\text { (east suburban } \\
\text { fringe) }\end{array}$ & $\begin{array}{l}\text { New } \\
\text { development }\end{array}$ & $\begin{array}{l}\text { Athletic activities } \\
\text { (shooting events) }\end{array}$ & $\begin{array}{l}\text { Parks and } \\
\text { promenades, } \\
\text { convention and } \\
\text { exhibition halls }\end{array}$ \\
\hline
\end{tabular}

(Continued) 
(Table 2. Continued)

\begin{tabular}{|c|c|c|c|c|}
\hline Name of cluster & Location & $\begin{array}{l}\text { Type of } \\
\text { development }\end{array}$ & $\begin{array}{l}\text { Main land uses and } \\
\text { activities clustered }\end{array}$ & $\begin{array}{l}\text { Complementary land } \\
\text { uses and activities }\end{array}$ \\
\hline $\begin{array}{l}\text { Aghios Kosmas } \\
\text { Olympic Sailing } \\
\text { Centre }\end{array}$ & $\begin{array}{l}\text { Aghios Kosmas } \\
\text { (south-east } \\
\text { suburban } \\
\text { fringe) }\end{array}$ & $\begin{array}{l}\text { New } \\
\text { development }\end{array}$ & $\begin{array}{l}\text { Athletic activities } \\
\text { (sailing events) }\end{array}$ & $\begin{array}{l}\text { Parks and } \\
\text { promenades, } \\
\text { convention and } \\
\text { exhibition halls }\end{array}$ \\
\hline $\begin{array}{l}\text { Vouliagmeni } \\
\text { Triathlon } \\
\text { Centre }\end{array}$ & $\begin{array}{l}\text { Vouliagmeni } \\
\text { (south-east } \\
\text { suburban } \\
\text { fringe) }\end{array}$ & $\begin{array}{l}\text { New } \\
\text { development }\end{array}$ & $\begin{array}{l}\text { Athletic activities } \\
\text { (triathlon, cycling) }\end{array}$ & $\begin{array}{l}\text { Parks and } \\
\text { promenades, } \\
\text { convention and } \\
\text { exhibition halls }\end{array}$ \\
\hline $\begin{array}{l}\text { Schinias Oympic } \\
\text { Rowing and } \\
\text { Canoeing } \\
\text { Centre }\end{array}$ & $\begin{array}{l}\text { (north-east } \\
\text { suburban } \\
\text { fringe) }\end{array}$ & $\begin{array}{l}\text { New } \\
\text { development }\end{array}$ & $\begin{array}{l}\text { Athletic activities } \\
\text { (canoe/kayak and } \\
\text { rowing) }\end{array}$ & $\begin{array}{l}\text { Parks and } \\
\text { promenades, } \\
\text { convention and } \\
\text { exhibition halls }\end{array}$ \\
\hline
\end{tabular}

and development programme (Beriatos and Gospodini, 2004). In most of Athens' Olympic complexes, the design scheme has been either the winning entry of an international or national architectural competition, or the outcome of a contract with pioneer architects at international level, such as Santiago Calatrava, who designed the main Olympic Sports Complex in Maroussi (Figure 6). Thus, in terms of morphology and landscape, these planned clusters of culture and leisure constitute epicentres characterised by innovative design and distinct architectural and urban morphology with international rather than local references.

In contrast to the dispersal of planned clusters throughout Attica, Athens' spontaneous clusters are mostly located in inner-city areas. In the past decade or so, economic activities such as leisure and night-time entertainment, high culture, technology-intensive and knowledge-rich enterprises, and highlevel financial intermediary services havegradually and in an unplanned way-been clustering in particular inner-city areas, transforming both place identity and landscape. Table 3 presents Athens' spontaneous clusters and their main characteristics in terms of type, location, degree of formation, kind of development, dominant and complementary land uses and activities, architectural forms, urban morphology and landscape. Most of them constitute spatial concentrations of culture, leisure, night-time entertainment and creative activities (Psiri, Piraeus Avenue, Metaxourgio), while only one represents a spatial concentration of technology-intensive and knowledge-rich enterprise, plus advanced financial intermediary services (Kifissias Avenue). The size of the clusters and their degree of formation differ: Psiri (Figure 7) and Kifissias Avenue (Figure 8) are extensive and dense spatial concentrations of homogeneous and/or harmonised economic activities and represent clearly identifiable epicentres. Piraeus Avenue (Figure 9) and Metaxourgio constitute what Hutton calls 'incipient precincts' of post-industrial economic activity, since the spatial distribution of culture, leisure, nighttime entertainment and creative activities is still sparse but concentration is on-going. Piraeus Avenue and Kifissias Avenue exhibit a linear development and a fish-bone structure, whereas Psiri is a robust, full-bodied formation covering a large area.

In terms of morphology and landscape, the clusters in Psiri, Metaxourgio and Piraeus 


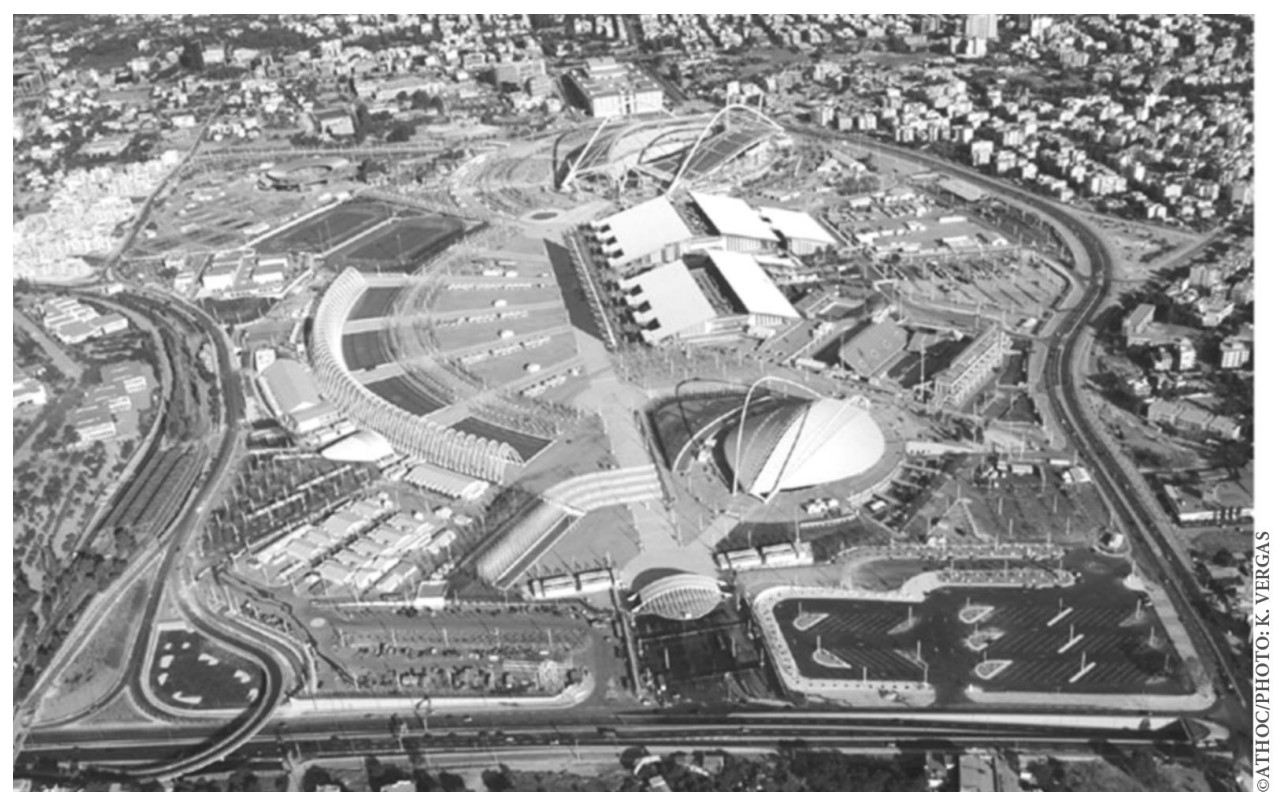

Figure 6. Athens, Maroussi: the main Olympic Sports Complex, designed by Santiago Calatrava

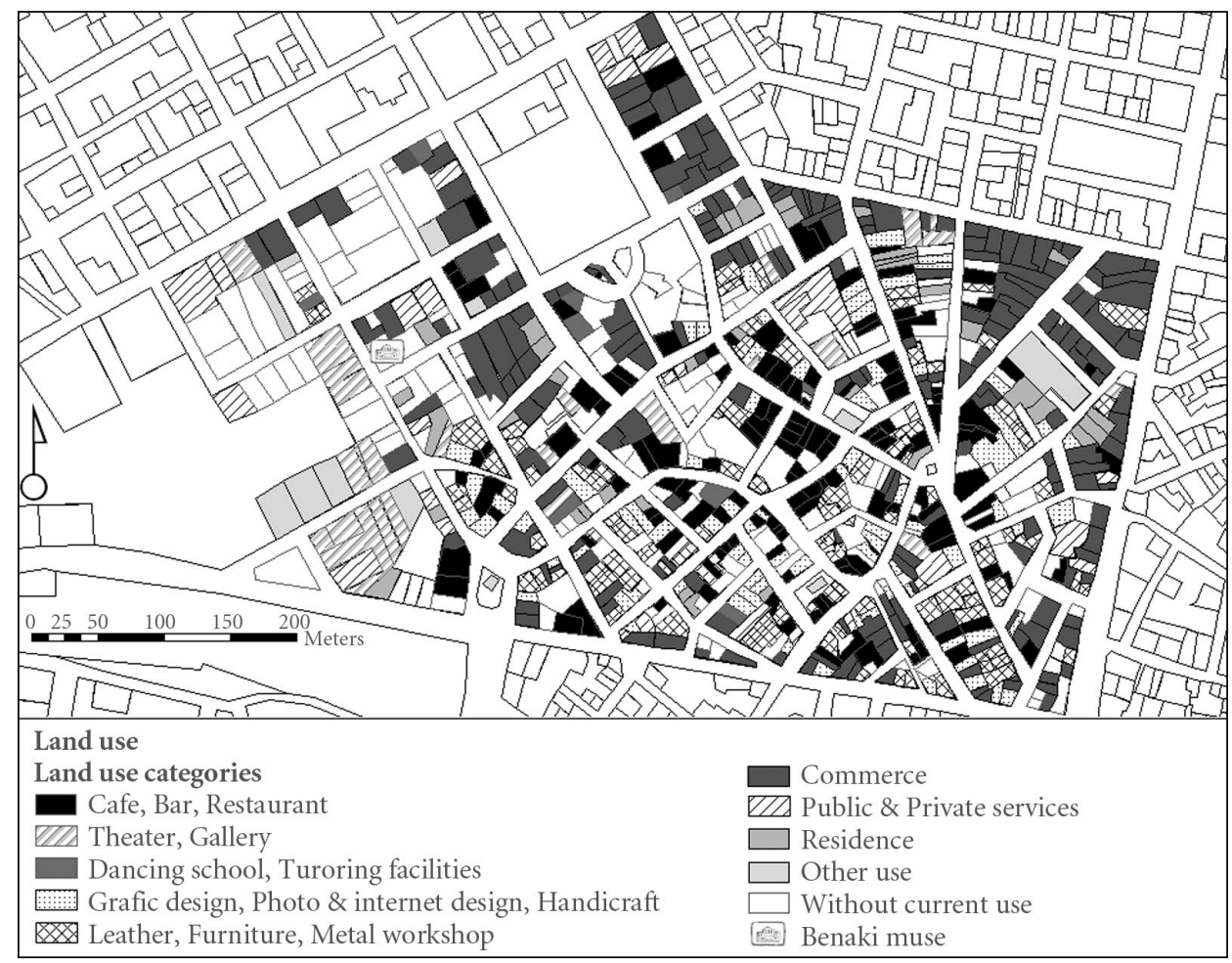

Figure 7. Psirri, Athens: land use map showing clustering of leisure and night-time entertainment, high culture and creative activities (handicrafts and design)

Source: Bellas (2006). 


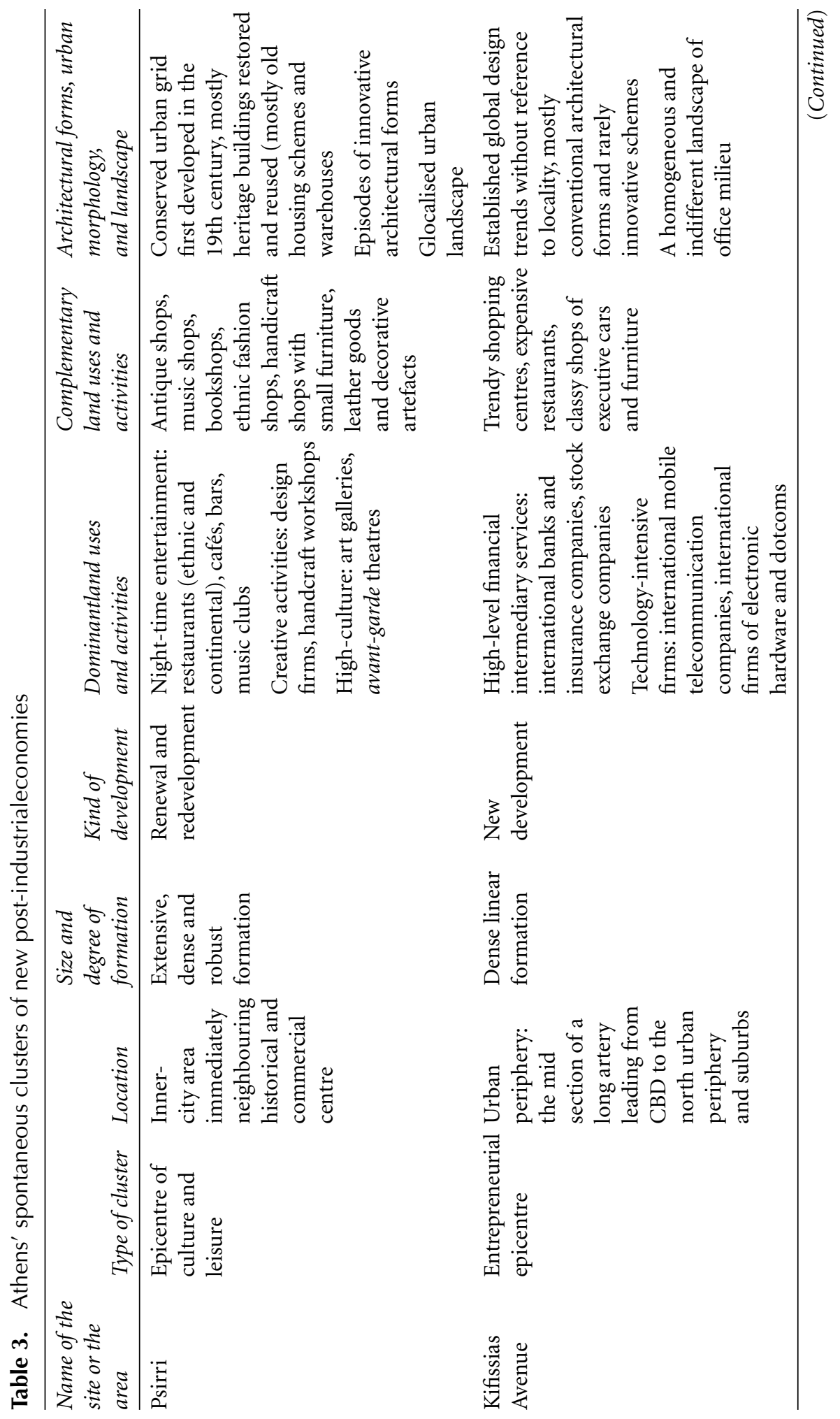




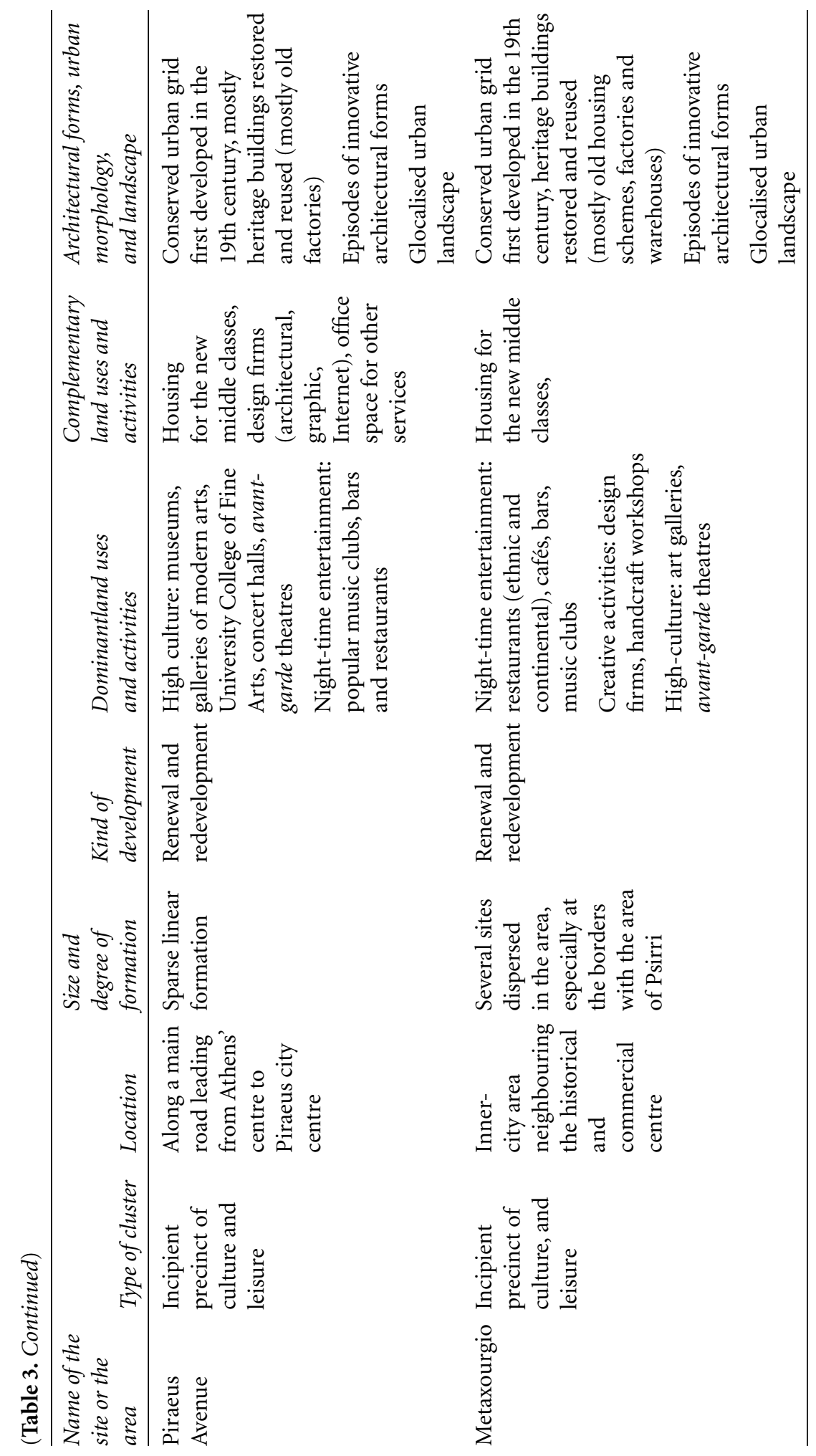




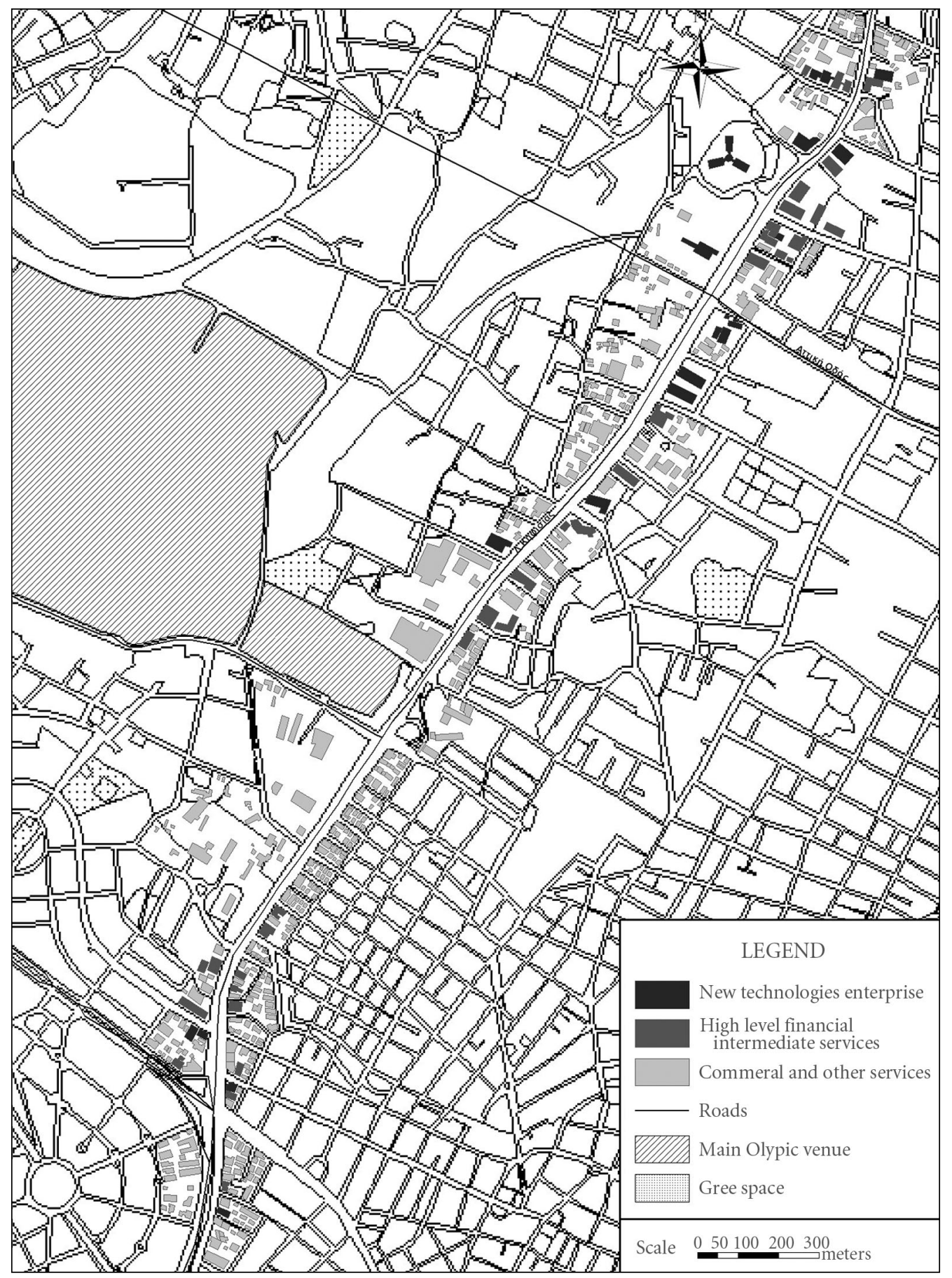

Figure 8. Part of Kifissias Avenue, Athens: land use map showing the gradual clustering of high level financial intermediary services and technology-intensive and knowledge-rich enterprises

Source: Tziamali (2006). 


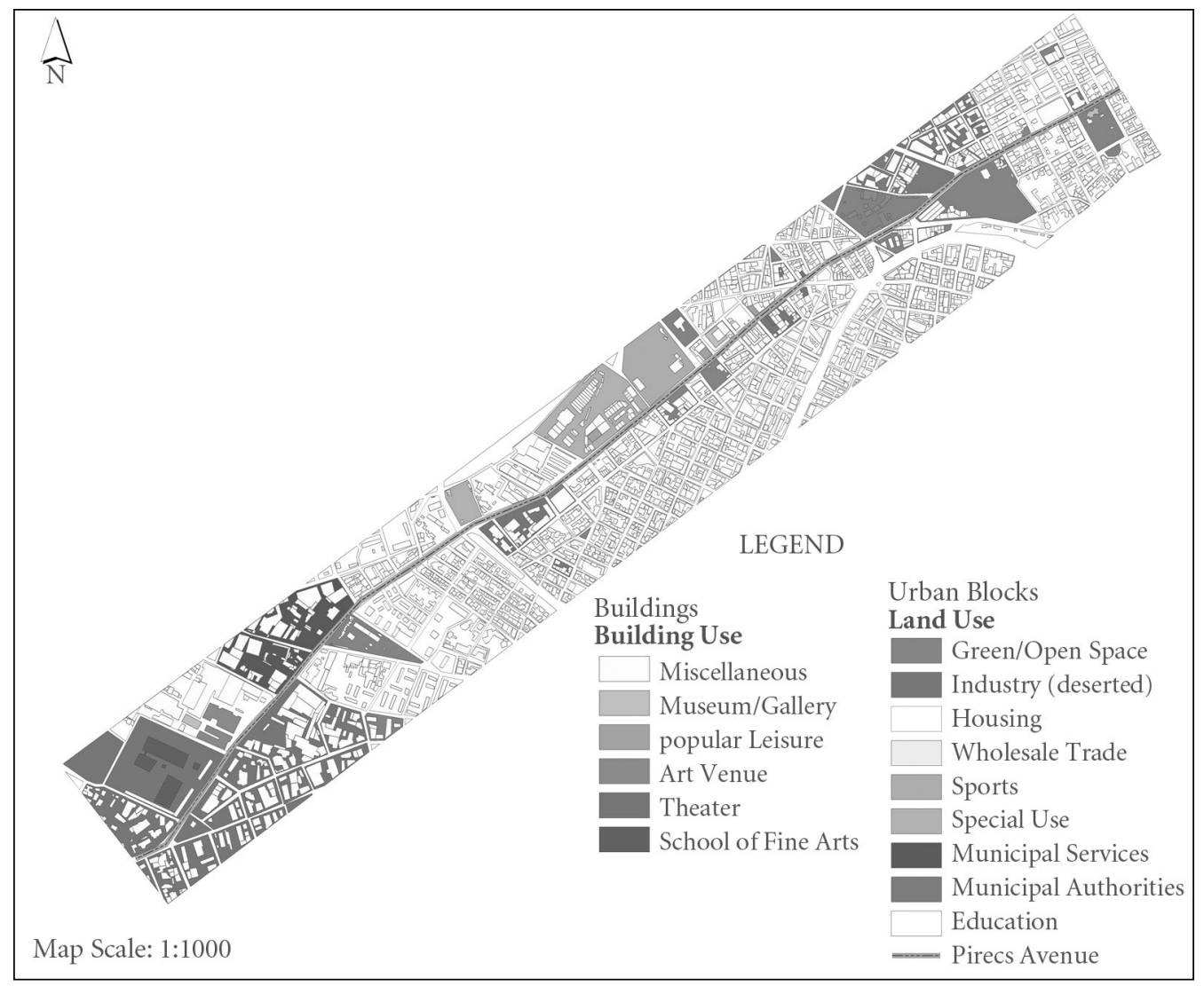

Figure 9. Part of Piraeus Avenue: land use map showing the gradual clustering of high-culture activities and leisure and night-time entertainment

Source: Papadema (2006).

Avenue are mostly located in 19th-century heritage buildings - traditional factory buildings (Figure 10), warehouses and low- to middle-class houses of naïve neo-classical style (Figure 11)—which have been restored and adapted to accommodate museums, theatres, galleries, night clubs, cafés, bars, restaurants and design offices. The reuse of old factory buildings is often based on the innovative redesign of space (see Figure 12) with a small number of new building schemes such as the New Benaki Museum of Modern Arts (Figure 13). These exhibit innovative design features and fill the gap between heritage buildings. Thus, from the point of view of architectural and urban morphology, these epicentres generate what has been termed 'glocalised landscapes' (see Beriatos and Gospodini, 2004; Gospodini, 2006). In contrast, the architectural forms and the urban morphology in the cluster along Kifissias Avenue are products of established global design trends, generating a conventional and monotonous office landscape lacking innovation and high quality design (see Figure 14).

\section{Spontaneous Clustering, Processes of Formation and the Policies Involved}

The formation of these clusters - as presented in Table 2-followed neither the directives nor the expectation of the Athens' master plan, but, rather, some intrinsic self-generating 


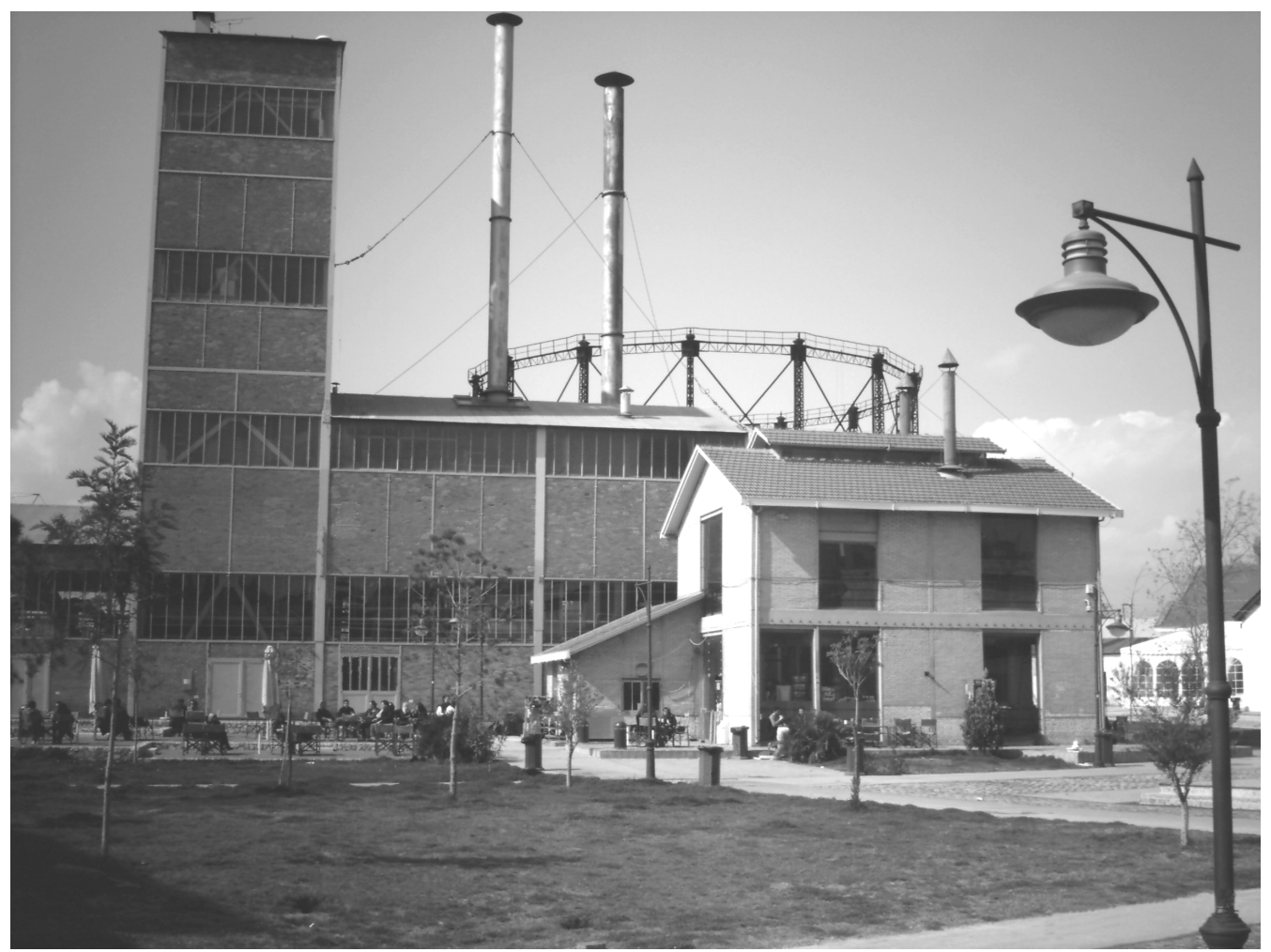

Figure 10. Piraeus Avenue: the old gas factory which was converted into a large culture and leisure centre run by the municipal authorities of Athens

rules associated with the particular areas' characteristics—spatial, morphological, cultural and economic. More specifically, looking at Athens' history of urban development in the past two centuries (see Sariyannis, 2000; Leontidou, 1989; Leontidou, 1990), a number of features can be noted.

Piraeus Avenue was developed in 1835 as the main road connecting Athens to the closely neighbouring harbour city of Piraeus. Owing to easy access to both cities and to the harbour, most sites along Piraeus Avenue were originally developed as industrial estates. In the 1970s, following the decline of traditional industries and the relocation of flourishing industrial plants in properly planned industrial estates in the exurban periphery, most of the industrial estates along Piraeus Avenue were abandoned. With a view to rehabilitating and regenerating this long artery $(28.5 \mathrm{~km})$, Athens' 1986 master plan enacted laws for the conservation and restoration of a large number of old industrial buildings for their architectural heritage value. Among all the legally approved land uses and activities, culture and leisure activities in particular spontaneously clustered in the old building complexes of Piraeus Avenue, owing to its particular characteristics: easy access to both Athens and Piraeus; large heritage buildings with high potential for redesign and reuse; abandoned sites and low real estate prices; and, a conserved environment of high cultural value. A recent land-use survey ${ }^{5}$ has shown that important high-culture institutions have moved into the area. ${ }^{6}$ In between these high-culture institutions are located popular music night clubs and bars. 


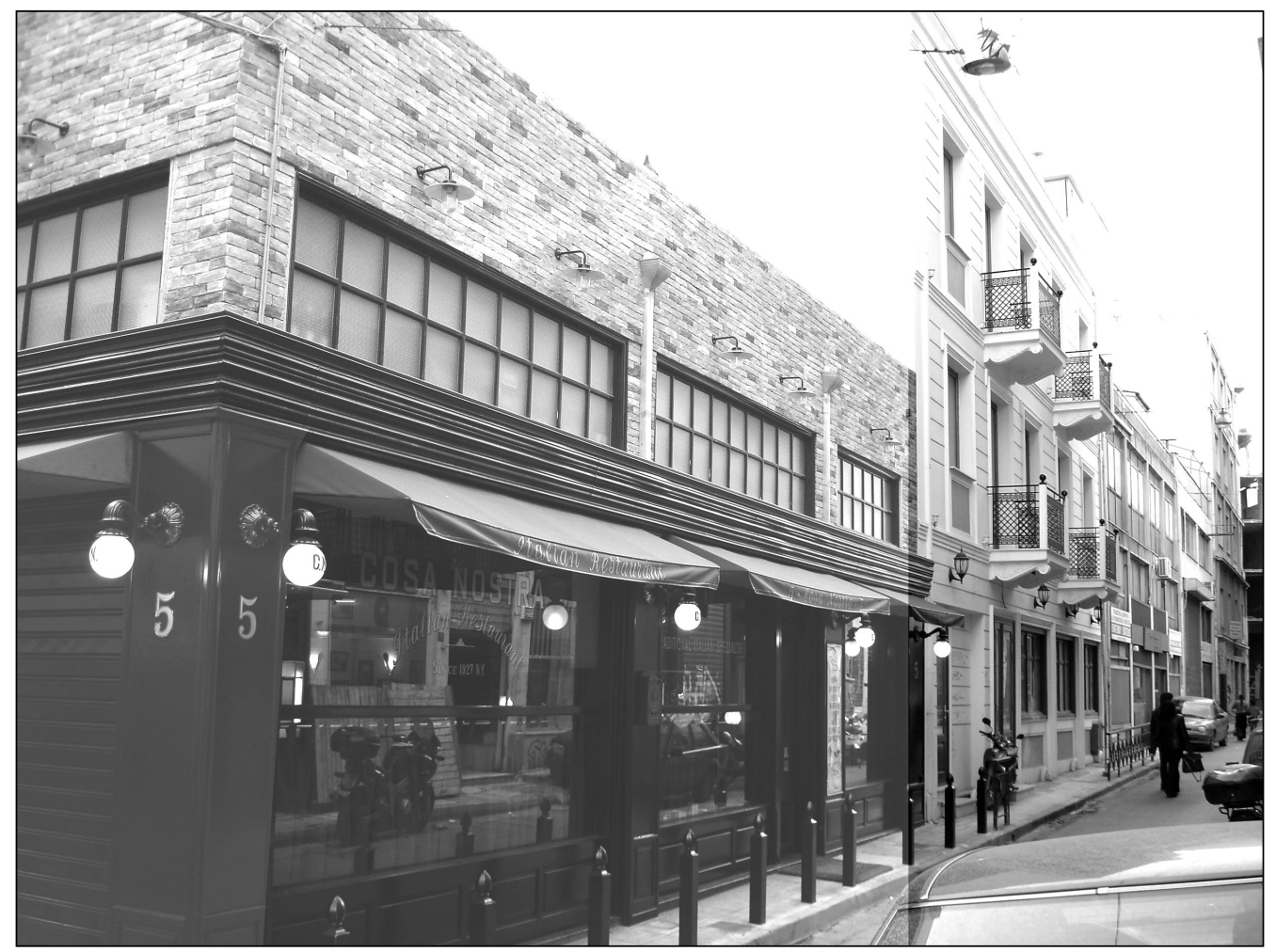

Figure 11. Psiri, Athens: a typical 19th-century street with low-middle-class and working-class houses, as well as small old small factories restored and reused to accommodate bars, restaurants and creative activities

Psiri and Metaxourgio were developed in the mid 19th century as residential areas of lower to middle classes. The social identity of these areas and their adjacency to Athens' commercial centre and the industries along Piraeus Avenue, encouraged the gradual development of family-operated workshops and small factories - mainly for leather goods, small furniture and small metal fabrication. By the end of the 19th century, Psiri and Metaxourgio had residential and industrial character as well, attracting new inhabitants seeking proximity to productive activities-especially to the gas factory and the silk factory. The inflow of new inhabitants continued until the mid 20th century-a period of major national migration to Attica. The demographic shrinking and deterioration of these areas started in the 1970s and was rooted in the decline of traditional industries, restrictions on the construction of new buildings owing to the need to preserve archaeological ruins, ${ }^{7}$ increasing car traffic and air pollution in the existing narrowroad grid, conflicts between incompatible land uses and activities such as housing and factories (Municipality of Athens, 1991). Stabilisation of the population levels came in the early 1990s with newcomers to these areas being mainly foreign economic immigrants and new middle class cohorts. The former were attracted by the low housing rents and the proximity to production activities, while pull factors for the latter included low real estate prices, inner-city amenities and the prospect of the regeneration of these areas in the framework of the city's preparation for 


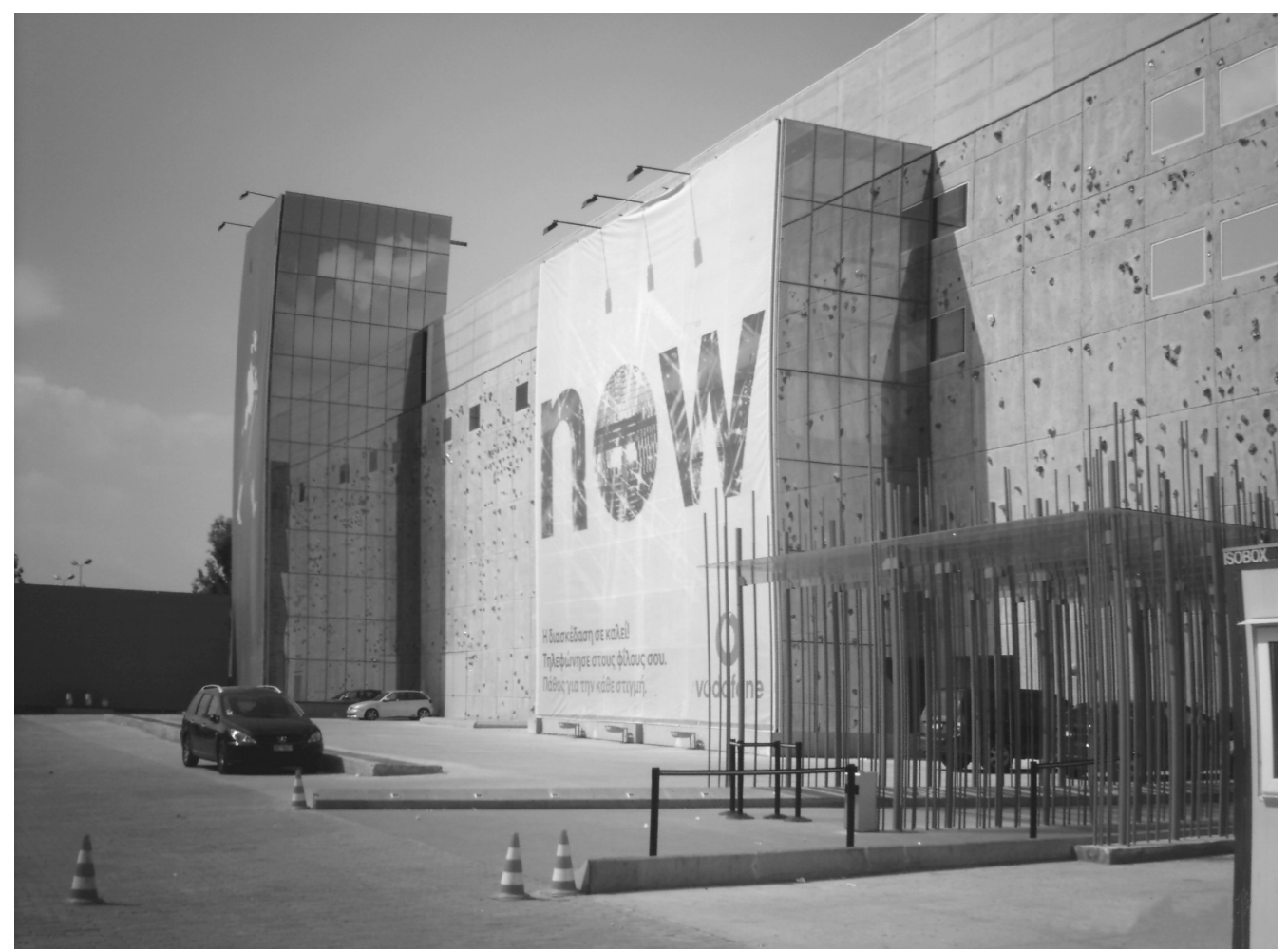

Figure 12. The north part of Piraeus Avenue, Athens: the Pantheon complex, accommodated in an old industrial estate and exhibiting an innovative redesign of the old buildings. It comprises the Athens Arena (a large auditorium for multiple performances), two night clubs for popular music, two cinemas, many commercial shops, five restaurants, a café, a roof garden with a pool, a hotel, a gym and a spa

the 2004 Olympics (Makrakis-Karachalios, 2006). The enhancement of these areas began with the 1991 Regeneration Plan of inner Athens, following the enactment of presidential decrees designed to control land use and solve conflicts, protect built heritage, ${ }^{8}$ and encourage renewal and redevelopment. However, the major spatial, economic and social transformations of these areas were facilitated by inherent factors, similar to those in Piraeus Avenue-namely, proximity to Athens' commercial centre, the existence of underused large industrial buildinggs with great potential for redesign and reuse, empty sites, low rents and real estate prices and a conserved urban fabric of high cultural value.
Appreciation of these virtues on the part of cultural, leisure and creative activities, such as theatres, design offices and art galleries, cafés, bars and restaurants, led to clustering in Psiri, whereas new middle classe cohorts started buying and moving into conserved and restored older houses.

A recent land use survey ${ }^{9}$ shows that diverse groups of economic activities are clustered in different parts of Psiri (see Figure 7 and also Table 4), forming five distinct sub-clusters: a sub-cluster of leisure and night-time entertainment occupying the geographical heart of the area; a sub-cluster of high culture, occupying a through corridor in the heart of the area; a sub-cluster of creative activities 
Table 4. The cluster of culture, leisure and creative activities in Psiri, Athens: spatial features of different groups of economic activities

\begin{tabular}{lcccc}
\hline & $\begin{array}{c}\text { Number of } \\
\text { enterprises }\end{array}$ & $\begin{array}{c}\text { Total surface } \\
\text { covered } \\
\text { (square metres) }\end{array}$ & $\begin{array}{c}\text { Mean surface } \\
\text { covered } \\
\text { square metres) }\end{array}$ & $\begin{array}{c}\text { Percentage of } \\
\text { total economic } \\
\text { activities area }\end{array}$ \\
\hline $\begin{array}{l}\text { Economic activities } \\
\text { entertainment (cafés, bars, } \\
\text { restaurants, music clubs) }\end{array}$ & 160 & 21952 & 137.20 & 20.17 \\
$\begin{array}{l}\text { High culture (theatres, art galleries) } \\
\text { Creative activities }\end{array}$ & 24 & 9467 & $394, .46$ & 8.70 \\
$\begin{array}{l}\text { Design firms (architectural design, } \\
\text { graphics, software design, Internet } \\
\text { services) }\end{array}$ & 88 & 11417 & 129.74 & 10.49 \\
$\begin{array}{l}\text { Handicraft shops and workshops } \\
\text { (leather goods, small furniture } \\
\text { and decorative goods, jewellery, } \\
\text { metalwork) }\end{array}$ & 106 & 15524 & 146.45 & 14.26 \\
$\begin{array}{l}\text { Education-special schools (arts, } \\
\text { design, dance, etc.) }\end{array}$ & 10 & 1713 & 171.30 & 1.57 \\
$\begin{array}{l}\text { Commercial shops (music shops, } \\
\text { old bookshops, antique shops, } \\
\text { hand-made low-cost jewellery, } \\
\text { decorative goods) }\end{array}$ & 347 & 38869 & 112.01 & 35.71 \\
$\begin{array}{l}\text { Services (bank branches, engineers } \\
\text { offices) }\end{array}$ & 27 & & & \\
$\begin{array}{l}\text { Total (for all economic activities in } \\
\text { the cluster) }\end{array}$ & 762 & 108832 & 142.82 & 100.00 \\
\hline
\end{tabular}

Source: Bellas (2006).

occupying the south-east part of Psiri; and two sub-clusters of commerce and services, occupying the north-western and the northeastern fringes of Psiri.

A decade after Psiri's transformation, Metaxourgio is nowadays an area in transition, essentially following Psiri's trajectory (see Makrakis-Karachalios, 2006). The 'delay' is rooted in the fact that the relocation of prohibited activities, such as factories, carworkshops and brothels, has followed a slower pace in Metaxourgio than in Psiri.

Kifissias Avenue was constructed in the 19th century as the main road connecting Athens to rural settlements in north Attica. Owing to favourable climatic conditions and the quality of the natural environment, northern Attica was initially developed as summer resort district in the mid 19th century and later as a suburban residential district for Athens' upper-middle class (Phelps et al., 2006). Although transport in the area was gradually improved by a suburban electric train line in 1885 and other road arteries later, Kifissias Avenue kept its character as the main connecting corridor between Athens' centre and north Attica (Sariyannis, 2000). Also, in contrast to landownership fragmentation in other areas, Kifissias Avenue was characterised by largesized private and public properties offering excellent opportunities for major development schemes (Aravantinos et al., 1997). This, combined with easy access to the city centre and the upper-middle-class suburbs, and the 


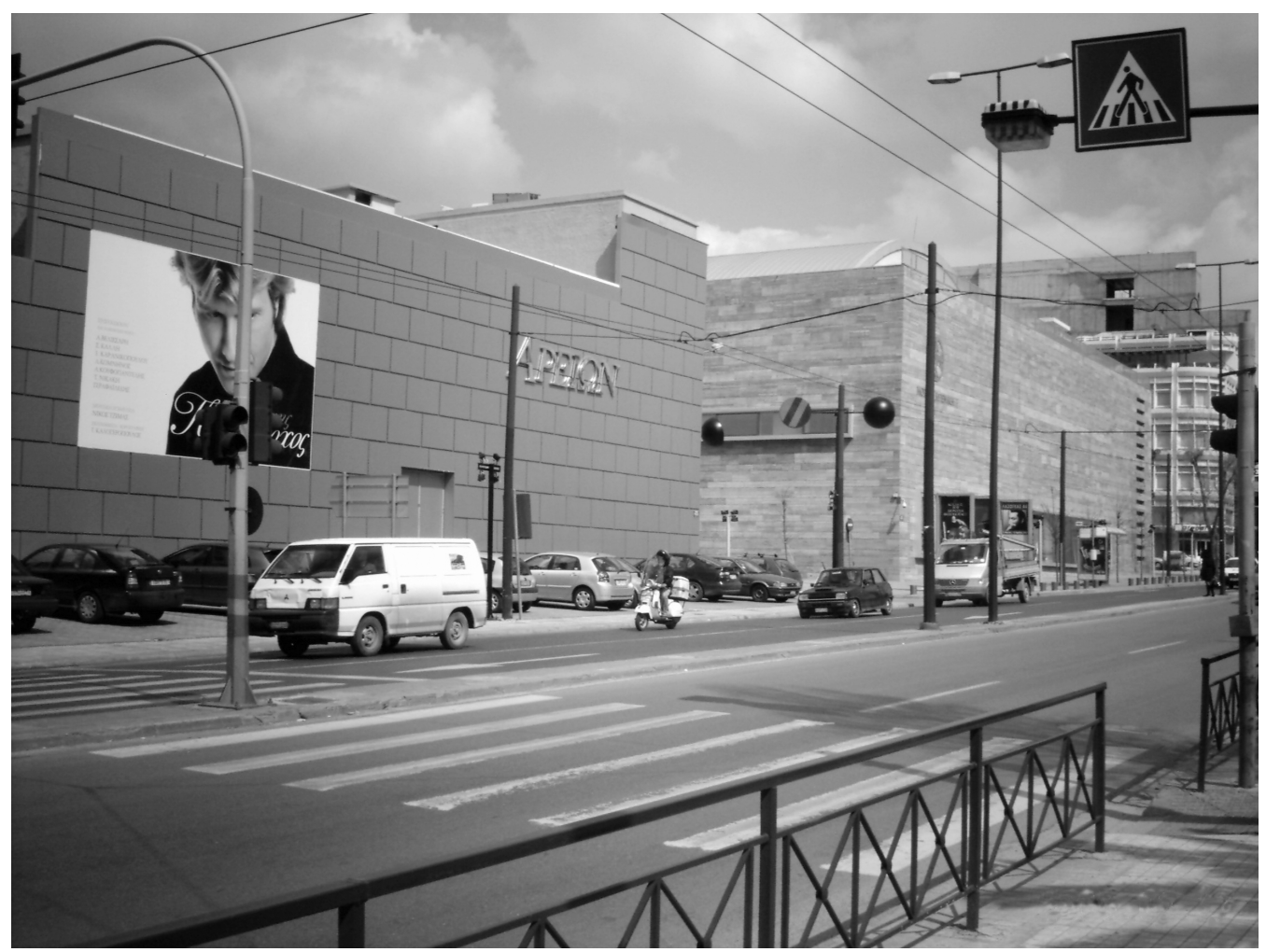

Figure 13. The north part of Piraeus Avenue, Athens: On the right is the New Benaki Museum of Modern Arts which as been the outcome of a national architectural competition; on the left is the Arreion night club for popular music

dramatic increase of technology-intensive and knowledge-rich firms and financial intermediary services in the 1990s, coupled with the lack of vacancies in Athens' CBD, has resulted in the construction of large office complexes along the mid part of Kifissias Avenue and a corresponding shift of the land use pattern. Before the 1990s, the dominant land uses were housing and commerce. Since the 1990s, international banks and insurance companies (Interamerican, Netherlanden), international telecommunication companies (Tim, Vodafone, Cosmote) (see Figure 14) and international companies of electronic hardware (IBM, Philips, Sony) and dotcoms have begun to cluster there in an unplanned and spontaneous way. Further, Athens' Olympic Sports Complex-i.e. the main athletic venue of the 2004 Olympics - was developed in the area. A recent land use survey ${ }^{10}$ indicates that in the mid section of Kifissias Avenue alone, there are currently no fewer than 45 buildings hosting financial intermediary services and 21 buildings accommodating technologyintensive and knowledge-rich enterprises.

\section{Athens' New Epicentres and Their Management}

With a view to optimising post-Olympics reuse and development of all epicentres of athletics, culture and leisure constructed for the 2004 Olympics (as presented in Table 2), the Greek central government founded 'Olympic Real Estates Ltd' in 2003-a new state institution exclusively concerned with this task. 


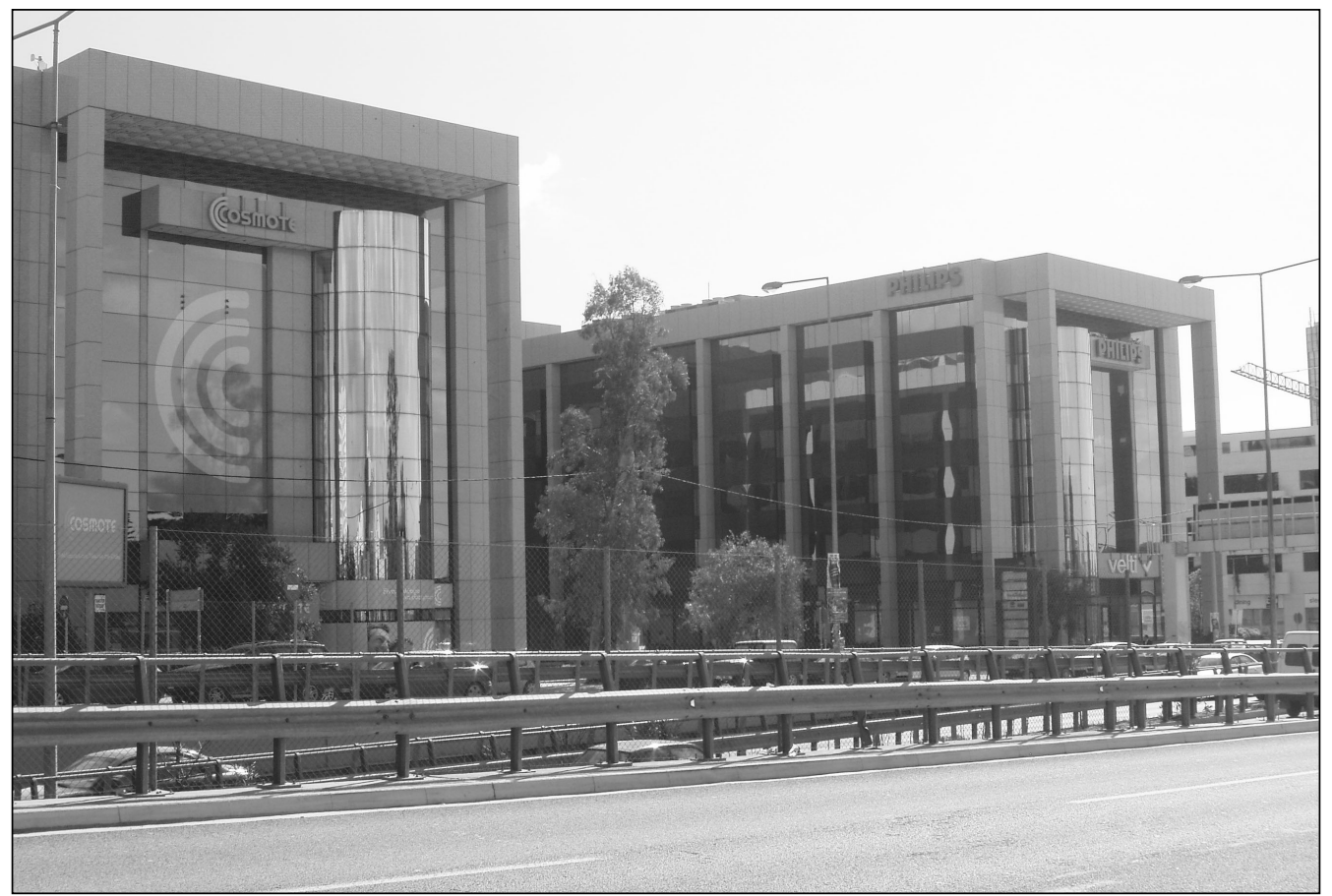

Figure 14. The mid section of Kifissias Avenue, Athens: a spontaneous entrepreneurial epicentre comprising international mobile telecommunication companies such as Tim, Vodafone and Cosmote; technology-intensive international companies, such as Philips, Sony, IBM, Media Markt; international banks, such as Marfin Bank and international insurance companies. The buildings exhibit conventional international design trends and generate a monotonous office landscape without innovation or high quality

Well before the period of the Games, Olympic Real Estates had prepared some outline plans for the post-Olympics reuse of these epicentres. However, following the shift of central government in Greece in the elections of April 2004, these plans became subject to a major revision by the new government. Four years after the Games, many of these epicentres are temporarily underused ${ }^{11}$ or not in use at all ${ }^{12}$ awaiting a master plan for their optimal reuse. This situation has created a major debate in Greek society as a whole-among political parties, and among politicians and experts. The main questions raised in this debate are

- Why have such epicentres having required huge public investment, for so long remained underused?
- Given successful international experience in this domain, why did the Greek government not set up well in advance a strategic plan for the post-Olympics reuse of these epicentres?

- Since it was known in advance that infrastructure for some sports that are not very developed or popular in Greece might be used only once during the Games, why were all athletic complexes constructed as permanent structures usually requiring large investments for both construction and maintenance?

Although still without a comprehensive strategic plan, 'Olympic Real Estates has, during the past two years, launched ad hoc public competitions concerning the reuse ${ }^{13}$ of several 
of the Olympics sites or parts of them-those most attractive to private investors and easily exploitable. It is striking that none of the state authorities or the local authorities of Attica has participated in these competitions; only private companies have shown interest in bidding for them (Beriatos, 2006). The privatisation of the Olympic epicentres has created a second wave of responses by politicians, NGOs and citizens.

Turning to Athens' spontaneous clusters, the issues of development and management were investigated by means of a questionnaire survey. ${ }^{15}$ The survey involved a total of 45 interviews with managerial personnel of enterprises in different economic activities in each of the case study clusters. Interviews were based on three questions

(1) Are there any positive synergies and/or negative effects produced by the close proximity of enterprises of the same kind in this area? And, if yes, which are they?

(2) Aiming at the sustainable development of this area, what interventions do you think should be made by the local or the state authorities?

(3) Regarding the future development of the enterprise you are working in, as well as other enterprises of the same kind in this area, what do you think could be achieved by means of co-operation between enterprises, and the communication and organisation of people working in them?

In the first question, all interviewees noted a series of positive synergies produced by the cluster, while almost no negative effects were mentioned. More specifically, interviewees in financial intermediary services and technology-intensive and knowledge-rich enterprises in Kifissias Avenue referred to the interfirm mobility of staff, informal contacts among the staff and the appreciation of the general atmosphere of the area as positive factors. Interviewees in the culture and leisure clusters in Psiri and Piraeus Avenue cited the positive synergies between high-culture activities (museums, theatres, galleries) and night-entertainment (bars, restaurants, music clubs). As these respondents observed, people choose to come to the area because they may combine a visit to a museum or an art gallery in the afternoon, with a theatrical play in the evening and a music club in the night. In contrast, interviewees in handicraft workshops complained that their enterprises are economically pressured by more profitable enterprises-such as night-time entertainment - to relocate and offer them space.

In the second question, interviewees in Psiri and Piraeus Avenue noted that local authorities and the state might do more for these areas-as indicated by the following observations

(1) Renewal and redevelopment in these areas are not yet complete. The pace of renewal and redevelopment should be accelerated in both the public and the private spheres while economic incentives should be established for attracting private investments.

(2) The existing network of pedestrian streets in Psiri should be expanded to cover most parts of the area.

(3) In both Psiri and Piraeus Avenue, public open spaces should be properly redesigned to maintain an identity as 'decent spaces' - this is not the case today for public open spaces neighbouring places of night-time entertainment.

(4) Public transport should be improved in Piraeus Avenue, with new bus and metro lines.

(5) The law prohibiting live music clubs and restaurants in Psiri and Piraeus Avenue should be abolished; and proper licences should be given to all such enterpriseswhich are anyway illegally operating and flourishing in these areas. 
In contrast to the constructive suggestions of the interviewees in Psiri and Piraeus Avenue, interviewees in Kifissias Avenue were largely satisfied with what has already been done in their area and had no suggestions.

In responding to the third question, interviewees in Piraeus Avenue noted that networking and co-ordination among museums and galleries-both public and private-might have very positive results; in this way, the area as a whole could host mega art events. They also mentioned the need for better marketing of the area-at least the construction of a website, something already existing for Psiri. ${ }^{16}$ Interviewees in Psiri were satisfied with the co-operation between enterprises and with the area's marketing. Interviewees in Kifissias Avenue were also satisfied with the progress of informal networks of co-operation among professionals and among enterprises.

\section{Conclusions: Post-industrial Trajectories of Large Cities in the core and Large Cities in the Developing Periphery of Europe: Seeking Differences}

The case study of Athens may help in highlighting aspects of the post-industrial trajectories of large cities in the developing periphery of Europe, as well as in defining differences between these cities and mature cities in Europe's economic core.

Regarding the formation of clusters, a major difference between the two groups of cities involves spatial planning and design: In Athens, the largest and densest clusters of post-industrial economic activity, notably Kifissias Avenue, Psiri and Piraeus Avenue, have not been planned as such, but rather have developed spontaneously, following some intrinsic pathway related to the areas' spatial and socioeconomic characteristics. In contrast, metropolitan cities and large cities in regions of growth economies (such as the core of Europe, North America and some regions of east and south-east Asia), endeavouring to maintain and/or upgrade their status within the global urban hierarchy, consciously plan, design and develop signifying or symbolic epicentres, endorsing the clustering of flourishing post-industrial economic activities (Gospodini, 2006). Many such planned epicentres have recently been developedwhether entrepreneurial epicentres like Berlin's Potzdamer Platz and Milan's Citylife scheme, both exhibiting innovative design of space, or culture and leisure epicentres like the Museums Quarter in Vienna, Rotterdam and The Hague, indicating a great

shift from a policy aimed at organising occasions for spectacular consumption to a more fine-tuned policy, aimed at creating spaces, quarters and milieus for cultural production and creativity (Mommas, 2004, p. 508).

In contrast to these generally successful international experiences, Athens' development strategies and trajectories are more varied. On the one hand, spontaneous entrepreneurial clusters like Kifissias Avenue, representing robust post-industrial economic formation, are consigned by local authorities and the state to a laissez-faire spatial development programme and conventional architectural schemes. On the other hand, planned epicentres of culture and leisure involving huge public funds, like those constructed for the 2004 Olympics, have failed to shape a new quarter of culture and leisure in the city's landscape, since they have been scattered throughout Attica. Moreover, they remain underused or even deserted places four years after the Games. This situation points to certain urban governance weaknesses in Athens - and perhaps in many large cities in the Mediterranean region and the European south-eastern periphery. Urban governance deficiencies represent another major difference between these groups of cities and mature large cities in the old core, or the expanding new core of Europe. 
The particularities of Mediterranean European cities in terms of spatial planning, urban governance and culture-in comparison with core European cities-have well been described and documented by Leontidou in both her early writings (1990 and 1993) and also recently (2006). According to Leontidou, spontaneous spatial development and unplanned urban expansion have been endogenous attributes of European Mediterranean cities in the second half of the 20th century, rooted in the fragmentation of landownership (see also Gospodini, 2001) and in the "anti-planning attitudes (of both people and government) and popular rights over land and housing allocation" (Leontidou, 1993, p. 954). The passage from traditional urban governance models to the 'entrepreneurial city' in the 1990s has certainly affected the urban economies and the landscapes of European Mediterranean cities. According to Leontidou (2006), they now represent hybrid entities between opposing edges such as laissez-faire/spatial planning, market-led development/public intervention and land speculation/spatial order.

Leontidou's argument may convincingly portray the situation in most Mediterranean European cities-Greek cities, Italian cities, French cities and Spanish cities. However, it should be noted that certain groups of Mediterranean European cities-for example, Catalan and Andalucian cities in Spain, with Barcelona ranking top and paving the way for Valencia, Seville and others-have lately made significant progress in issues of spatial planning, design and urban governance mirrorong ${ }^{1}$ mature core European cities or even precede them. ${ }^{17}$

Examining the differences in terms of spatial planning, design and urban governance among Mediterranean groups of cities, and especially between Spanish and Greek cities, Leontidou had emphatically written as early as 1995 that "Spain and Greece present opposite trajectories" (Leontidou, 1995, p. 155).
As she argues, in the 1960s, cities in both countries developed in a context of 'informality' and 'reciprocity'. Yet by the 1990s, following two decades of modernisation efforts, the trajectories of Greek and the Spanish cities had become strongly divergent in terms of spatial planning, urban policies and governance, and local initiative

Spanish urban success stories during the 1990s, relying on urban-oriented civic pride, local initiative and international events contrast sharply with Greek urban experiences, blocked by formidable objective and intersubjective obstacles to development (Leontidou, 1995, p. 155).

Among these obstacles to development, one may distinguish the following

(1) Landownership fragmentation and the lack of public land in inner-city areas hinder the implementation of large and innovative planning and design interventions.

(2) The established urban governance 'model' and practices operate not only in post-Olympics Athens, but in all large and medium-sized Greek cities.

As far as the former are concerned, the redevelopment/renewal/redesign of underused or non-used old harbour sites in innercity areas offers a unique opportunity and a challenge for Greek cities (see Gospodini, 2001) to respond to the need for spatial arrangements to foster the clustering of postindustrial economies. In contrast to the lack of public land and the landownership fragmentation in the inner city, these waterfront areas contain a considerable amount of nonfragmented public land, suitable for major planning interventions, innovative design and the creation of post-industrial economic epicentres.

Turning to the latter, the established urban governance model in contemporary Greek 
cities is a kind of hybrid structure between 'Europeanisation' and 'traditional political behavioural logic' (Getimis and Grigoriadou, 2004). Although European integration has had strong direct and indirect effects on urban governance in Greece

the combination of a centralised state structure with a weak civil society and a state-dependent local government has led to hierarchical clientelistic networks, party-dominated political relations, an individualistic and confrontational culture and phenomena of local corporatism (Getimis and Grigoriadou, 2004, p. 13).

However, differences among Mediterranean groups of cities-like those noted earlier between Greek and the Spanish cities_-in terms of spatial planning, design, urban policies, governance and achievements in the era of intercity competition and post-industrial economies, exist within the context of a general overall trend. Of course, there are exceptions to this trend; and there are success and failure stories in all groups of cities. For instance, among the stories of the 'successful' Catalan and Andalucian cities, there is the failure story of Seville's planned cluster for the World Fair EXPO '92. And within the generally 'disadvantaged' group of Greek cities, there are success stories of spatial planning, design and urban governance, like that of the conversion of Athens' old gas factory site into a creative, lively and flourishing cluster of culture and leisure facilities.

\section{Notes}

1. This kind of learning first termed 'collective learning' by Lawson and Lorenz (1999), 'situated business learning' by Raffo et al. (2000) and 'situated creativity' by Jeffcutt and Pratt (2002), involves the creation and further development of a base of common or shared knowledge among individuals making up a productive system which allows them to co-ordinate their actions in the resolution of the technological and organisational problems they confront.
2. This research concerns culture and leisure clusters in Greek cities, such as Psiri in Athens, Ladadika in Thessaloniki and Palia in Volos. Research was carried out by students on the MSc course 'Urban Planning and Development', at the University of Thessaly, under the supervision of the author of this paper.

3. See CEC, 1992; RECLUS/DATAR in Verhille et al. (1995).

4. For example, Barcelona 'used' the 1992 Olympics for redeveloping a large and central waterfront area which had formerly been a declined industrial area (see Marshall, 2000) and Lisbon 'used' World Fair EXPO '98 for redeveloping an abandoned industrial site, located in the geographical heart of the city on the River Tagus waterfront (see Carriere and Demaziere, 2002 ).

5. The land use survey was carried out by MSc students in the Department of Planning and Regional Development, University of Thessaly, as part of their projects supervised by the author of this paper (see Papadema, 2006).

6. These are the New Benaki Museum of Modern Arts (see Figure 14); Technopolis (see Figure 10) hosting music and art events; Hellinikos Cosmos, a museum of virtual reality shows and interactive technology-intensive education; The School of Fine Arts, University of Athens; the Bios Centre, a multimedia art centre for innovative arts and experimental performances; and five theatres.

7. Metaxourgio is built on the 'Dimosio Sima'the ancient cemetery for eminent Athenians.

8. This heritage consisted of old houses in naïve neo-classical style.

9. The land use survey was carried out by students in the Department of Planning and Regional Development, University of Thessaly, as part of their projects supervised by the author of this paper (see Bellas, 2006).

10. The land use survey was carried out by diploma students in the Department of Planning and Regional Development, University of Thessaly, as part of their projects (see Tziamali, 2006).

11. That is, they are occasionally used for hosting important athletic, political and cultural events (such as the musical event, Eurovision 2006).

12. This refers to athletic complexes for sports that are neither developed nor popular in Greece, such as badminton, indoor cycling and canoeing/kayaking. 
13. In Athens' Olympic Sports Complex in Maroussi, the Media Centre has already been converted and hosts the Ministry of Education while the Radio-Television Centre has been renewed and accommodates a shopping and leisure centre - the Mall - which is the biggest such centre in Attica. The Stadium will house multiplex cinemas and a bowling centre. Nikea's Olympic Indoor Hall will be reused for the educational activities of University of Piraeus. In Goudi, Olympic Modern Pentathlon Complex, the badminton gym has been converted into a centre for the performing arts (musical concerts, ballet dancing, theatre, etc.). In Faliron's Olympic Coastal Zone Complex, the tae-kwon-do gym has been converted into a conference centre, while the National Library, the National Opera House and an ecological theme park will also be developed there. In Galatsi, the Olympic Complex for table tennis and rhythmic gymnastics will be converted into a shopping and leisure mall. The Hellinikon Olympic Complex for baseball, softball, hockey, canoeing/ kayaking, handball and fencing will become a water-leisure theme park.

14. See http://www.olympicproperties.gr/default_ gr.asp.

15. The questionnaire survey was carried out in March and April 2006 by students of the MSc and Diploma courses in the Department of Planning and Regional Development, University of Thessaly, as part of their projects supervised by the author of this paper (see Bellas, 2006; Papadema, 2006; and Tziamali, 2006).

16. The site advertising all activities and enterprises in Psiri is www.psiri.gr.

17. Some scholars go as far as arguing that local identities are on the edge of breaking down (see Luna-Garcia, 2003).

\section{References}

Aitchison, C. and Evans, T. (2003) The cultural industries and a model for sustainable regeneration: manufacturing 'pop' in the Rhondda valleys of south Wales, Managing Leisure, 8(3), pp. 133-144.

Aravantinos, A., Aggelidis, M., Serraos, C. and Antoniou, L. (1997) Land uses along the main road network. Urban Planning Research Centre,
National Technical University of Athens [in Greek with English summary].

Atkinson, R. (2000) Measuring gentrification and displacement in Greater London, Urban Studies, 37(1), pp. 149-165.

Atkinson R. (2004) The evidence on the impact of gentrification: new lessons for the urban renaissance?, European Journal of Housing Policy, 4(1), pp. 107-131.

Attfield, A. (1997) Bread and circuses? The making of Hoxton's cultural quarter and its impact on urban regeneration in Hackney, Rising East, 1(3), pp. 133-135.

Bailly, A., Jensen-Butler, C. and Leontidou, L. (1996) Changing cities: restructuring, marginality and policies in urban Europe, European Urban and Regional Studies, 3(2), pp. 161-176.

Bassett, K., Griffiths, R. and Smith, I. (2002) Cultural industries, cultural clusters and the city: the example of natural history film-making in Bristol, Geoforum, 33, pp. 165-177.

Bellas, C. (2006) Psiri, Athens: investigating the formation and management of the cluster of new economies. MSc research project, Department of Planning and Regional Development, University of Thessaly.

Belussi, F. and Sedita, S. R. (2008) The management of 'events' in the Veneto performing music cluster: bridging latent networks and permanent organizations, in: P. Cooke and L. Lazzaretti (Eds) Creative Cities, Cultural Clusters and Local Economic Development, pp. 237-257. Cheltenham: Edward Elgar Publishing.

Beriatos, E. (2006) Athens: the transformation of a Mediterranean metropolis: problems and perspectives after Olympics 2004. Paper presented at the 42nd ISoCaRP International Congress, Istanbul, September.

Beriatos, E. and Gospodini, A. (2004) Glocalizing urban landscapes: Athens and the 2004 Olympics, Cities, 21(3), pp. 187-202.

Bianchini, F. (1993) Culture, conflict and cities: issues and prospects for the '90s, in: F. Bianchini and M. Parkinson (Eds) Cultural Policy and Urban Regeneration: The West European Experience, pp. 1-20. Manchester: Manchester University Press.

Caincross, F. (1998) The Death of Distance: How the Communications Revolution Will Change Our Lives. Boston, MA: Harvard Business School Press. 
Capello, R. (1999) Spatial transfer of knowledge in high technology milieu: learning versus collective learning processes, Regional Studies, 33, pp. 353-365.

Carriere, J. P. and Demaziere, C. (2002) Urban planning and flagship development projects: lessons from EXPO '98, Lisbon, Planning Practice and Research, 17(1), pp. 69-79.

Castells, M. (1996) The Rise of the Network Society. Cambridge, MA: Blackwell.

CEC (Commission of the European Communities) (1992) Urbanisation and the function of cities in the European Community. Regional Development Studies No. 4, CEC, Brussels.

Clarke, D. B. (1997) Consumption and the city, modern and postmodern, International Journal of Urban and Regional Research, 21(2), pp. 218-237.

Costa, P. (2008) Creativity, innovation and territorial agglomeration in cultural activities: the roots of the creative city, in: P. Cooke and L. Lazzaretti (Eds) Creative Cities, Cultural Clusters and Local Economic Development, pp. 183-210. Cheltenham: Edward Elgar Publishing.

Couch, C., Leontidou, L. and Petschel-Held, G. (Eds) (2007) Urban Sprawl in Europe: Landscapes, Land-use Change and Policy. Oxford: Blackwell.

Coyle, D. (1998) The Weightless Economy. London: Capstone.

Creigh-Tyte, A. (2005) Measuring creativity: a case study in the UK's designer fashion sector, Cultural Trends, 14(2), pp. 157-183.

Crewe, L. (1996) Material culture: embedded firms, organizational networks and the local economic development of a fashion quarter, Regional Studies, 30(3), pp. 257-272.

Evans, G. (2003) Hard-branding the cultural city: from Prado to Prada, Journal of Urban and Regional Research, 27(2), pp. 417-440.

Evans, G. (2005) Measure for measure: evaluating the evidence of culture's contribution to regeneration, Urban Studies, 42(5/6), pp. 959-983.

Featherstone, M. (1989) Consumer Culture and Postmodernism. London: Sage.

Florida, R. (2002) The Rise of the Creative Class. London: Routledge.

Florida, R. (2004) Cities and the Creative Class. London: Routledge.
Florida, R. (2005) The Flight of the Creative Class: The New Global Competition for Talent. London: Harper Collins.

Getimis, P. and Grigoriadou, D. (2004) The Europanisation of urban governance in Greece: a dynamic and contradictory process, International Planning Studies, 9(1), pp. 5-25.

Gospodini, A. (2001) Urban waterfront redevelopment in Greek cities: a framework of redesigning space, Cities, 18(5), pp. 285-296.

Gospodini, A. (2006) Portraying, classifying and understanding the emerging landscapes in the post-industrial city, Cities, 23(5), pp. 311-330.

Graham, S. and Guy, S. (2002) Digital space meets urban place: sociotechnologies of urban restructuring in downtown San Francisco, City, 6(3), pp. 369-382.

Hall, P. (2000) Creative cities and economic development, Urban Studies, 37(4), pp. 639-649.

Hannigan, J. (1998) Fantasy City: Pleasure and Profit in the Postmodern Metropolis. London: Routledge.

Hannigan J. (2003) Symposium on branding, the entertainment economy and urban place building: introduction, International Journal of Urban and Regional Research, 27(2), pp. 352-360.

Harvey, D. (1989) The Condition of Postmodernity. Oxford: Blackwell.

Hitters, E. and Richards, G. (2002) The creation and management of cultural clusters, Creativity and Innovation Management, 11(4), pp. 234-247.

Hobbs, D., Lister, S., Hadfield, P. et al. (2000) Receiving shadows: governance and liminality in the night-time economy, British Journal of Sociology, 51(4), pp. 701-717.

Hollands, R. and Chatterton, P. (2003) Producing nightlife in the new urban entertainment economy: corporatization, branding and market segmentation, International Journal of Urban and Regional Research, 27(2), pp. 361-385.

Hubbard, P. (2003) A good night out? Multiplex cinemas as sites of embodied leisure, Leisure Studies, 22(3), pp. 255-272.

Hutton, T. A. (2000) Reconstructed production landscapes in the postmodern city: applied design and creative services in the metropolitan core, Urban Geography, 21(4), pp. 285-317.

Hutton, T. A. (2004a) Post-industrialism, postmodernism and the reproduction of Vancouver's central area: retheorising the 21st-century city, Urban Studies, 41(10), pp. 1953-1982. 
Hutton, T. A. (2004b) The new economy of the inner city, Cities, 21(2), pp. 89-108.

Hutton, T. A. (2006) Spatiality, built form, and creative industry development in the inner city, Environment and Planning A, 38, pp. 1819-1841.

Jeffcutt, P. and Pratt, A. C. (2002) Managing creativity in the cultural industries, Creativity and Innovation Management, 11(4), pp. 225-233.

Jensen-Butler, C. (1997) Competition between cities, urban performance and the role of urban policy: a theoretical framework, in: C. JensenButler, A. Shachar and J. van Weesep (Eds) European Cities in Competition, pp. 3-32. Aldershot: Ashgate.

Keeble, D. and Wilkinson, F. (1999) Collective learning and knowledge development in the evolution of regional clusters of high technology SMEs in Europe, Regional Studies, 33(4), pp. 295-303.

Krätke, S. (2002) Network analysis of production clusters: the Potsdam/Babelsberg film industry as an example, European Planning Studies, 10(1), pp. 27-54.

Lash, S. M. and Urry, J. (1994) Economies of Signs and Space. London: Sage.

Lawson, C. and Lorenz, E. (1999) Collective learning, tacit knowledge and regional innovative capacity, Regional Studies, 33, pp. 305-317.

Lazzeretti, L. (2008) The cultural districtualization model, in: P. Cooke and L. Lazzaretti (Eds) Creative Cities, Cultural Clusters and Local Economic Development, pp. 93-120. Cheltenham: Edward Elgar Publishing.

Leontidou, L. (1989) Cities of silence: working class colonisation of urban space, Athens and Pireaus1909-1940. Piraeus Bank Group Cultural Foundation, Athens [in Greek with English summary].

Leontidou, L. (1990) The Mediterranean City in Transition: Social Change and Urban Development. Cambridge: Cambridge University Press.

Leontidou, L. (1993) Postmodernism and the city: Mediterranean versions, Urban Studies, 30(6), pp. 949-965.

Leontidou, L. (1995) Repolarization of the Mediterranean: Spanish and Greek cities in neo-liberal Europe, European Planning Studies, 3(2), pp. 155-172.

Leontidou, L. (2006) Multi-culture and heterotopia in the Mediterranean urban landscape: from spontaneous urbanisation to the entrepreneurial city, in: A. Gospodini and E. Beriatos (Eds) New Urban Landscapes and the Greek City, pp. 70-84. Athens: Kritiki Publications [in Greek].

Leontidou, L., Afouxenidis, A., Kourliouros, E. and Marmaras, E. (2007) Infrastructure-related urban sprawl: mega events and hybrid peri-urban landscapes in southern Europe, in: C. Couch, L. Leontidou and G. Petschel-Held (Eds) Urban Sprawl in Europe: Landscapes, Land-use Change and Policy, pp. 71-98. Oxford: Blackwell.

Lever, W. F. (2001) The Post-Fordist' city, in: R. Paddison (Ed.) Handbook of Urban Studies, pp. 273-283. London: Sage.

Luna-Garcia, A. (2003) Cities of Spain, localities on the edge of an identity breaking down, Cities, 20(6), pp. 377-379.

Makrakis-Karachalios, C. (2006) The area of Metaxourgio in transition: dynamics and actors' tactics. Paper presented at the 42nd ISoCaRP International Congress, Istanbul, September.

Marshall, T. (2000) Urban planning and governance: is there a Barcelona model?, International Planning Studies, 5(3), pp. 299-319.

Martin, B. (1998) Knowledge, identity and the middle class: from collective to individualised class formation?, The Sociological Review, 46(4), pp. 653-686.

McNeil, D. and While, A. (2001) The new urban economies, in: R. Paddison (Ed.) Handbook of Urban Studies, pp. 296-308. London: Sage Publications.

Miles, M. (2005) Interruptions: testing the rhetoric of culturally led urban development, Urban Studies, 42(5/6), pp. 889-911.

Miles, S. and Paddison, R. (2005) Introduction: the rise and rise of culture-led urban regeneration, Urban Studies, 42(5/6), pp. 833-839.

Mommaas, H. (2004) Cultural clusters and the post-industrial city: towards the remapping of urban cultural policy, Urban Studies, 41(3), pp. 507-532.

Municipality of Athens (1991) Metaxourgio: regeneration study (phase $A$ ). Municipality of Athens [in Greek].

Newman, P. and Smith, I. (2000) Cultural production, place and politics on the south bank of the Thames, International Journal of Urban and Regional Research, 24(1), pp. 9-24.

NSSG (National Statistical Service of Greece) (2000) Special censuses of economic activities and enterprises. NSSG, Athens. 
Papadema, P. (2006) Pireaus Avenue, Athens: investigating the formation and management of the cluster of new economies. MSc research project, Department of Planning and Regional Development, University of Thessaly.

Petrakos, G. and Economou, D. (1999) Internationalisation and structural changes in the European urban system, in: D. Economou and G. Petrakos (Eds) The Development of Greek Cities, pp. 13-44. Athens: Gutenberg and University of Thessaly Publications [in Greek].

Phelps, N. A., Parsons, N., Ballas, D. and Dowling, A. (2006) Kifissia: a playground of the Athenians, in: N. A. Phelps, N. Parsons, D. Ballas and A. Dowling (Eds) Post-suburban Europe: Planning and Politics at the Margins of Europe's Capital Cities, pp. 68-93. London: Palgrave Macmillan.

Pratt, A. C. (2000) New media, the economy and new spaces, Geoforum, 31, pp. 425-436.

Propris, L. de and Hypponen, L. (2008) Creative clusters and governance: the dominance of the Hollywood film cluster, in: P. Cooke and L. Lazzaretti (Eds) Creative Cities, Cultural Clusters and Local Economic Development, pp. 258-286. Cheltenham: Edward Elgar Publishing.

Raffo, C., O'Connor, J., Lovatt, A. and Banks, M. (2000) Attitudes to formal business training and learning amongst entrepreneurs in the cultural industries: situated business learning through 'doing with others', Journal of Education and Work, 13(2), pp. 215-230.

Ramachandran, K. (2003) How dotcoms can be winners: a customer dissatisfaction approach to analysis, Venture Capital, 5(3), pp. 191-216.

Razi, M. A., Tarn, J. M. and Siddiqui, F. A. (2004) Exploring the failure and success of dotcoms, Information Management \& Computer Security, 12(3), pp. 228-244.

Roberts, M. (2006) From 'creative city' to 'no-go areas': the expansion of the night-time economy in British town and city centres, Cities, 23(5), pp. 331-338.

Sariyannis, G. (2000) Athens 1830-2000: Urban Development, Planning and Transport. Athens: Symmetry Editions [in Greek].

Scott, A. (2000) The Cultural Economy of Cities. London: Sage.

Scott, A. (2006) Industrial development: geography and the creative field revisited, Small Business Economics, 26(1), pp. 1-24.
Scott, A. J. (1997) The cultural economy of cities, International Journal of Urban and Regional Research, 21(2), pp. 323-339.

Shaw, D. V. (2001) The post-industrial city, in: R. Paddison (Ed.) Handbook of Urban Studies, pp. 284-296. London: Sage Publications.

Shaw, S., Bagwell, S. and Karmowska, J. (2004) Ethnoscapes as spectacle: reimaging multicultural districts as new destinations for leisure and tourism consumption, Urban Studies, 41(10), pp. 1983-2000.

Short, J. (1989) Yuppies, yuffies and the new urban order, Transactions of the Institute of British Geographers, 14, pp. 173-188.

Soja, E. (1989) Postmodern Geographies. New York: Verso.

Soja, E. (2000) Postmetropolis: Critical Studies of Cities and Regions. Oxford: Blackwell.

Storper, M. (1995) The resurgence of regional economies, ten years later: the region as a nexus of untraded interdependencies, European Urban and Regional Studies, 2, pp. 191-221.

Swyngedouw, E. (2004) Globalisation or 'glocalisation'? Networks, territories and rescaling, Cambridge Review of International Affairs, $17(1)$, pp. $25-48$.

Swyngedouw, E. and Baeten, G. (2001) Scaling the city: the political economy of 'glocal' development-Brussels 'conundrum', European Planning Studies, 9(7), pp. 827-849.

Swyngedouw, E., Moulaert, F. and Rodriguez, A. (2002) Neoliberal urbanization in Europe: large-scale urban development projects and the new urban policy, Antipode, 34(3), pp. 542-577.

Turok, I. (2003) Cities, clusters and creative industries: the case of film and television in Scotland, European Planning Studies, 11(5), pp. 549-565.

Tziamali, H. (2006) Kifissias Avenue, Athens: investigating the formation and management of a spontaneous cluster of technology-intensive firms and high-level financial intermediary services. Diploma dissertation, Department of Planning and Regional Development, University of Thessaly.

Verhille, P., Leroy, D. and Viorgard, J. L. (1995) Atlas de la Grand Europe. Paris: Ellipses.

Zukin, S. (1991) Landscapes of Power: From Detroit to Disney World. Berkeley, CA: University of California Press.

Zukin, S. (1995) The Cultures of Cities. Cambridge, MA: Blackwell Publishers Ltd. 